\title{
Morphological Characteristics of Cambodia Mekong Delta and Tonle Sap Lake and Its Response to River-Lake Water Exchange Pattern
}

\author{
Zhaoming Xu*, Changwen Li*\#, Anqiang Li, Zhongqiong You*, Wei Yao, Yongsheng Chen, \\ Liyao Huang
}

Changjiang Institute of Survey, Planning, Design and Research, Changjiang Water Resources Commission, Wuhan, China

Email: "lichangwen@cjwsjy.com.cn

How to cite this paper: $\mathrm{Xu}, \mathrm{Z} . \mathrm{M} ., \mathrm{Li}, \mathrm{C} . \mathrm{W}$., Li, A.Q., You, Z.Q., Yao, W., Chen, Y.S. and Huang, L.Y. (2020) Morphological Characteristics of Cambodia Mekong Delta and Tonle Sap Lake and Its Response to River-Lake Water Exchange Pattern. Journal of Water Resource and Protection, 12, 275-302.

https://doi.org/10.4236/jwarp.2020.124017

Received: March 1, 2020

Accepted: April 5, 2020

Published: April 8, 2020

Copyright $\odot 2020$ by author(s) and Scientific Research Publishing Inc. This work is licensed under the Creative Commons Attribution International License (CC BY 4.0).

http://creativecommons.org/licenses/by/4.0/ (c) (i) Open Access

\begin{abstract}
Tonle Sap Lake is the largest river-connected lake, buffer area and ecological zone of Mekong River, which plays a huge role in dispelling flood peak and compensating water, and the conservation of biological diversity. The river-lake relationship between Mekong River and Tonle Sap Lake is unique and has always been a major focus in the international community. The land terrain and under-water topography were used to analyze the morphological characteristics of Cambodia Mekong Delta and Tonle Sap Lake. Long series of hydrological data of river-lake controlling stations were used to analyze the water level variation characteristics and water volume exchange pattern between Mekong River and Tonle Sap Lake, and the response relationship to river-lake morphological characteristics were also researched. The results show that: Cambodia Mekong Delta and Tonle Sap Lake Area is low-lying and flat with gentle channel gradient and water surface gradient, making the relationship between water level and area (or volume) smooth. The channel storage capacity of Mekong River and Tonle Sap River is not enough compared to the inflow, so vast flooding plain is extremely prone to be inundated, making the flood relationships between the left and right banks become very complicated. Tonle Sap Lake is a seasonal freshwater lake with water flowing in and flowing out, and the timing and intensity of water exchange with Mekong River are closely related to the water flow resistance at the exit section of Tonle Sap Lake and the cross-sectional area of Tonle Sap River, which can be reflected by the river-lake water level difference and the water level of Tonle Sap River. Affected by the river-lake morphological characteristics, the water
\end{abstract}

*These authors contributed equally to this work.

\#The author is the corresponding author. 
exchange intensity between Mekong River and Tonle Sap Lake is great. Tonle Sap Lake not only stores $14.4 \%$ of flood volume $\left(39.7\right.$ billion $\left.\mathrm{m}^{3}\right)$ from the Mekong River every year, but also supplies $29.7 \%$ of dry water (69.4 billion $\mathrm{m}^{3}$ ) to the Mekong River. Influenced by the adjustment of the floodplain, the water level fluctuation of Mekong River and Tonle Sap Lake is slow, and the rising and droop rates of water level are positively correlated with the floodplain storage area. The research results will help to understand the relationship mechanism between Mekong River and Tonle Sap Lake and provide a scientific basis for the comprehensive governance of Cambodia Mekong Delta and Tonle Sap Lake Area.

\section{Keywords}

Tonle Sap Lake, Mekong River, Morphological Characteristic, River-Lake Relationship, Water Exchange Pattern, Response Relationship

\section{Introduction}

Both of Mekong Delta and Tonle Sap Lake Area are in the tropical monsoon climate; more than $90 \%$ of the rainfall are from the rainy season. The unique hydrological environment and geographical location determine the special morphological characteristics of the Mekong Delta and Tonle Sap Lake Area and the exchange pattern of them, laying the essential role that Tonle Sap Lake plays in the wetland ecosystem of the Mekong River Basin and the world. The catchment area of the junction of Tonle Sap River and Mekong River is about 749,000 $\mathrm{km}^{2}$, accounting for $92 \%$ of the total basin area. Since then, more than $95 \%$ of the runoff has transferred to the Mekong River Basin [1]. The Mekong Delta and the Tonle Sap Lake Area are low-lying, and the left and right banks are basically in a natural state. The discharge capacity of Mekong River and Tonle Sap River is seriously insufficient compared with the enormous upstream flood. Under the current flood control and disaster mitigation system, the flood control capacity of the main urban area of Phnom Penh is about 100-year return period, the flood control capacity of Kampong Cham is about 20-year return period, the flood control capacity of most important townships along the river (such as Kratie, Tboung Khmum, Leuk Daek, Kampong Thom, etc.) is 5 - 10-year return period, and the current flood control capacity of most farmland is less than 5-year return period, making the flooding frequent, flood disaster almost occur every year, and the flooding lasts for a long time, and the overland flood volume is vast [2] [3]. Apart from the influence from the upstream, it is also affected by the downstream tidal roof, causing the high flood level of Mekong River mainstream and the Tonle Sap Lake last for a long time, and the flooding process subsides slowly [1].

Affected by topography and upstream inflow conditions, the relationship between the Mekong River and Tonle Sap Lake is complicated, and the water ex- 
change intensity is high. The flood of Mekong River reversely flows into Tonle Sap Lake during the rainy season. Tonle Sap Lake is the largest storage place for the Mekong River floods, significantly reducing the flood threat of Mekong River. The slow-flowing-out water of Tonle Sap Lake in the dry season maintains a certain amount of water volume and water level in the lower reaches of the Mekong River downstream Phnom Penh, which is an indispensable water source for the navigation and irrigation of the Mekong Delta. As a result, the water lev$\mathrm{el}$, area and volume of the lake in the flood and dry season of Tonle Sap Lake are quite different. The highest water level measured in Tonle Sap Lake is $10.54 \mathrm{~m}$, the corresponding area is $15,261 \mathrm{~km}^{2}$, and the volume is about 78.7 billion $\mathrm{m}^{3}$. The measured minimum water level is $1.11 \mathrm{~m}$, the relevant area is $2053 \mathrm{~km}^{2}$, and the volume is about 800 million $\mathrm{m}^{3}$, and the extreme ratio of area between the maximum and minimum values is 7, and that of volume reaches 101 [4].

The Tonle Sap Lake Area is the most complex large freshwater wetland in the Cambodian water system. It is an essential flood storage and ecological frontage in the Mekong River Basin. It is a paradise for waterfowl and aquatic animals. It is called the "heart of Cambodia" and "lake of life" by the Cambodian people. The Tonle Sap Lake Area wetland is significant for the conservation of international biodiversity and the ecological security of the Mekong Delta. The unique morphological characteristics of the Mekong Delta and Tonle Sap Lake and the study of water exchange patterns between them will help to understand the relationship mechanism between the Mekong River and the Tonle Sap Lake and provide a scientific basis for the comprehensive management of the Mekong Delta and Tonle Sap Lake Area.

At present, the research results are few and lack systematic. Based on different sources of topographic data and various methods, the water level-area (volume) curves of Tonle Sap Lake were constructed [4]-[11], the ability of Tonle Sap Lake to regulate the flood of Tonle Sap Lake basin and Mekong River mainstream was studied [5], the time and magnitude variation characteristics of the water exchange between the Mekong River and the Tonle Sap Lake and the corresponding hydrological conditions were analyzed [12] [13], and the flood control planning schemes for the Cambodia Mekong Delta and Tonle Sap Lake Area were proposed [13] [14]. The Yangtze River Water Resources Commission, Cambodian Ministry of Water and Meteorology, and Korean government proposed a comprehensive water resources planning plan for the Cambodia Mekong Delta and the Tonle Sap Lake Area [2] [15] [16]. The influence of water facilities on the water level of the Mekong River and Tonle Sap Lake was studied [17], the effects of Mekong River flow changes on the Tonle Sap Lake flood pulse were analyzed [18], and the impact of flood pulse changes on the Tonle Sap Lake ecosystem was investigated [19]. However, these results have not revealed the correlation between river-lake water exchange pattern and the morphological characteristics of the Mekong Delta and Tonle Sap Lake Area. Therefore, it is necessary to carry out in-depth research on the morphological characteristics of the Mekong Delta and Tonle Sap Lake and river-lake exchange pattern, revealing the 
mechanism of the relationship between Mekong River and Tonle Sap Lake.

\section{Materials and Methods}

\subsection{Study Area}

The Lancang River originates in the Zadu County of Yushu Tibetan Autonomous Prefecture, Qinghai Province, China. And it flows via Qinghai Province, Tibet Autonomous Region, and Yunnan Province. Also, it flows out of the border in the Xishuangbanna Dai Autonomous Prefecture in the south of Yunnan Province. After leaving China, the name of the Lancang River turns into the Mekong River, which flows through Myanmar, Laos, Thailand, Cambodia, and Vietnam. In the end, it enters the South China Sea in the west of Ho Chi Minh City, Vietnam [1]. The entire area of the Lancang-Mekong River Basin is 812,400 $\mathrm{km}^{2}$, the total length of the mainstream is around $4880 \mathrm{~km}$, and about $5060 \mathrm{~m}$ drop of the mainstream with the average gradient $1.04 \%$. In addition, the whole basin area of Mekong River is $648,800 \mathrm{~km}^{2}$, which occupies $79.8 \%$ of the entire basin area of the Lancang-Mekong River, the length of mainstream is $2719 \mathrm{~km}$, which occupies $55.7 \%$ of the total length of the Lancang-Mekong River, and the natural drop is $477 \mathrm{~m}$, which occupies $9.4 \%$ of the whole drop of the Lancang-Mekong River. The Mekong River is divided into upstream, midstream, downstream and delta by Vientiane, Pakse, and Kratie. Firstly, the drainage area of upstream is $134,600 \mathrm{~km}^{2}$ with $1107 \mathrm{~km}$ of the length; secondly, the midstream has $246,600 \mathrm{~km}^{2}$ of drainage area with $753 \mathrm{~km}$ of distance. Next, the downstream has $106,200 \mathrm{~km}^{2}$ of drainage area with $331.3 \mathrm{~km}$ of length. Eventually, the drainage area of delta is $161,200 \mathrm{~km}^{2}$ (including Tonle Sap Lake) with $527.8 \mathrm{~km}$ of distance [14]. The river network of the Mekong Delta is dense, and the water system is created by variability, complexity, and instability. The rivers above the Phnom Penh are flooding, especially in the rainy season, which overflows the banks of the Mekong River, and enhances the flood plains up to $50 \mathrm{~km}$ wide for several weeks [20] [21] [22]. The Mekong River is linked to the Tonle Sap Lake, which is the largest freshwater lake in Southeast Asia's with $120 \mathrm{~km}$ long Tonle Sap River at Chaktomuk in Phnom Penh. The Tonle Sap Lake has a drainage area of $86,000 \mathrm{~km}^{2}$ and a multi-year average lake area of $6176.8 \mathrm{~km}^{2}$ with a volume of 15.14 billion $\mathrm{m}^{3}$. The Mekong River is divided into the Lower Mekong River and the Bassac River by Phnom Penh, and then divided into nine sea rivers in Vietnam. The overview of the Mekong River Basin is shown in Figure 1.

\subsection{Terrain Data Sources and Processing}

The 1:50,000 land-based terrain in Cambodia, the 1:100,000 underwater terrain of Tonle Sap Lake Area, and the 1:20,000 underwater topographic of Mekong River and the Tonle Sap River is used as data resources. ArcGIS is used to vectorize and bond the terrain data of Mekong Delta and Tonle Sap Lake Area, and construct DEM to perform elevation simulation and analyze its morphological characteristics. 


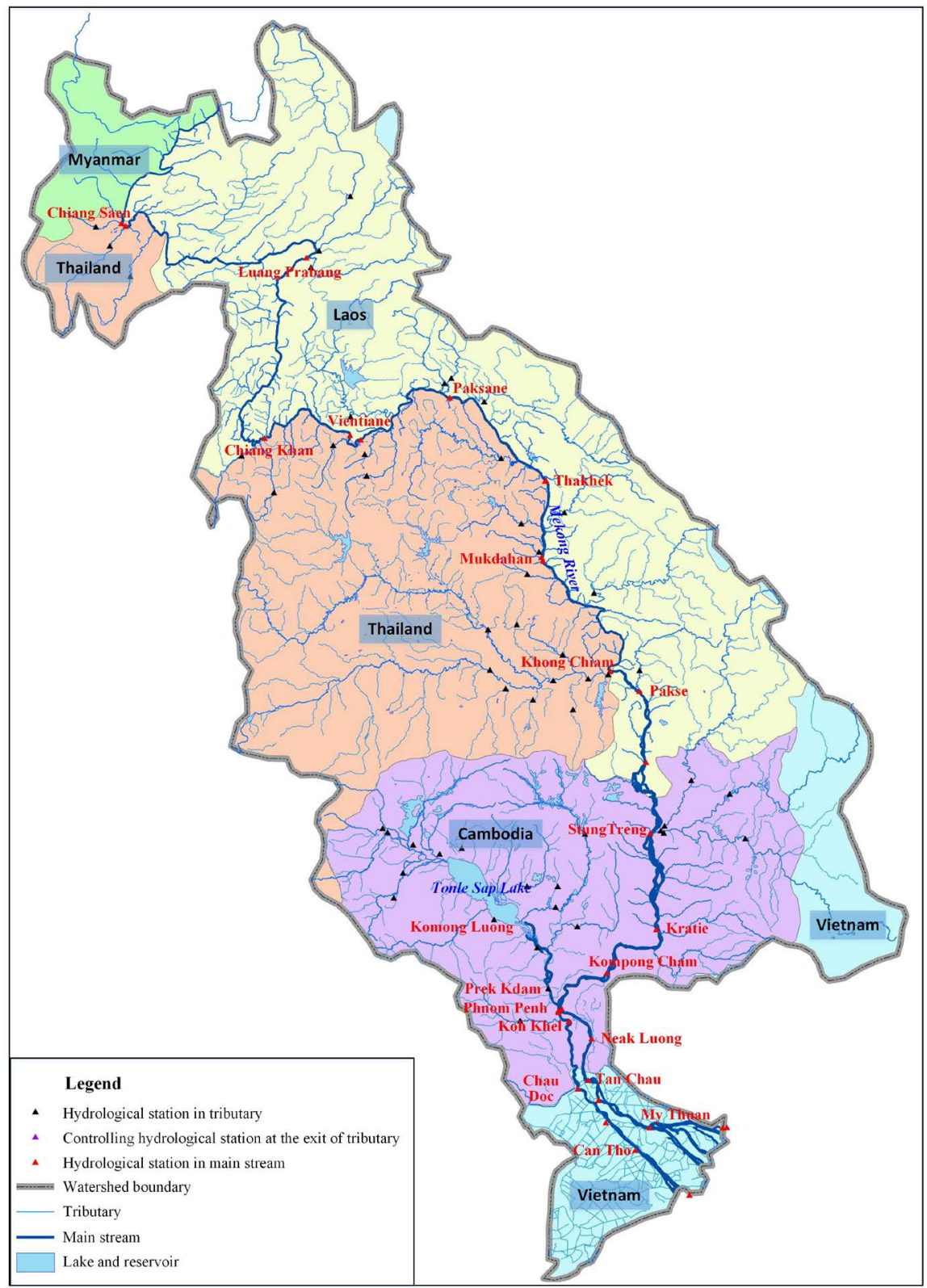

Figure 1. The overview of the Mekong River Basin.

\subsubsection{Morphological Characteristics of Cambodia Mekong Delta}

1) Topographic features

The area of Cambodia Mekong Delta is $29,200 \mathrm{~km}^{2}$. The northwest and northeast are the mountainous area in the upper reaches of the tributary, with a high altitude and an area of about $1 / 3$. The central, southeast, and southwest are flood plains composed of complex river networks connected by lakes, with low terrain and an area of about 2/3. The topographic of Cambodia Mekong Delta is shown in Figure 2.

2) Planform morphology

The entire mainstream of the Mekong Delta in Cambodia is about $297 \mathrm{~km}$ long, while the straight line is only nearly $196 \mathrm{~km}$ long and the river bend is 


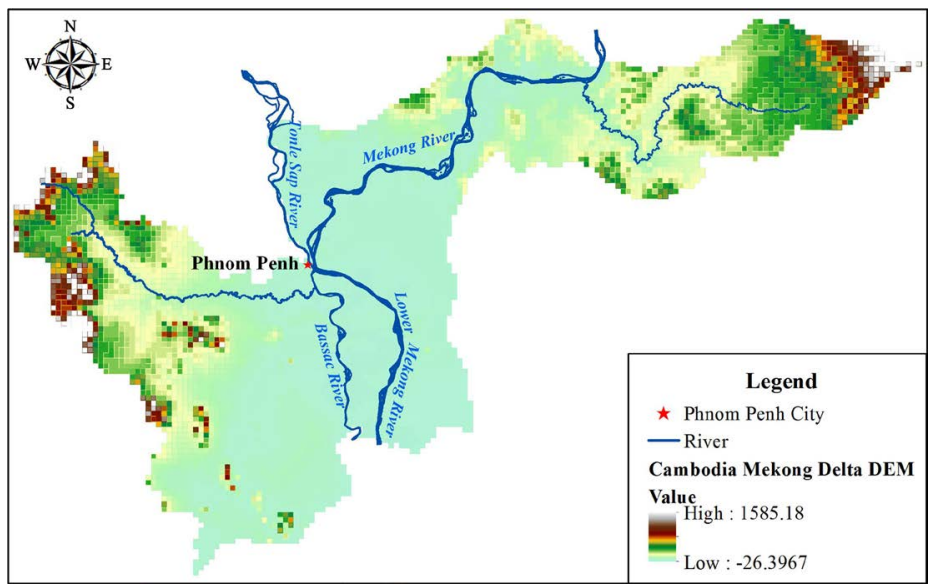

Figure 2. Topographic map of Mekong Delta.

about 1.52. According to the characteristics of watercourse and flood, the Cambodia Mekong Delta can roughly be divided into two sections: the reach between Kratie and Phnom Penh and the reach between Phnom Penh and Cambodia-Vietnam border. The reach between Kratie and Phnom Penh section is a typical meandering-type river channel with the mainstream length of about 209 $\mathrm{km}$. The river channel changes from alluvial to silt. The Mekong River system is unstable, complex, and variable. The river section is rapidly widened and exceeds $3 \mathrm{~km}$. There are sandbanks and small islands in the center of the river, and many side branches produced. The water flow is slow; sediments are deposited from the water bodies and stored on the riverbed. A vast floodplain appears along the river near Kampong Cham City, with a catchment area of about 17,000 $\mathrm{km}^{2}$. The section from Phnom Penh to Cambodia-Vietnam border is a branching channel with the mainstream length of $99 \mathrm{~km}$ and a catchment area of 12,200 $\mathrm{km}^{2}$. The Mekong River is divided into two parts: Lower Mekong River (left) and Bassac River (right) by Chaktomuk.

3) Cross section morphology

The Mekong Delta has branching sections and single sections of the cross-section. The single section cross-section is narrower than the branching section. The cross-section of branching section has the following three characters: first, more branching section, and more complicate section shape. Second, compared with single section, its section shape is wider and shallower. The width and depth increase with the size of curvature of the branching section. Third, the branching section remains the characters of riverbed, and the main slot is clearly tilted to one side in the curve branch. The shoreline of Mekong Delta River is generally in a natural state with low elevation. The current flood control capacity is 5 10 -year return period, and the two banks are broad flood plains. The typical section morphology is shown in Figure 3.

4) Longitudinal profile morphology

The mainstream of the Mekong River and Bassac River in the Cambodia Mekong Delta is about $297 \mathrm{~km}$ and $80 \mathrm{~km}$ long, respectively, and the average river 


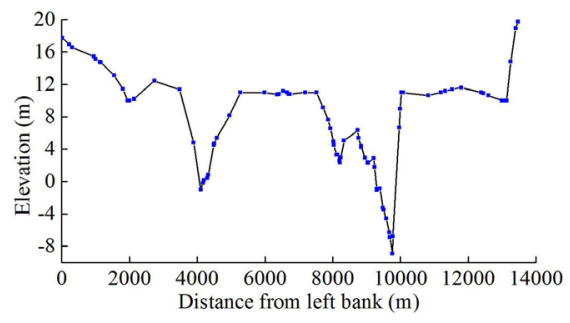

(a)

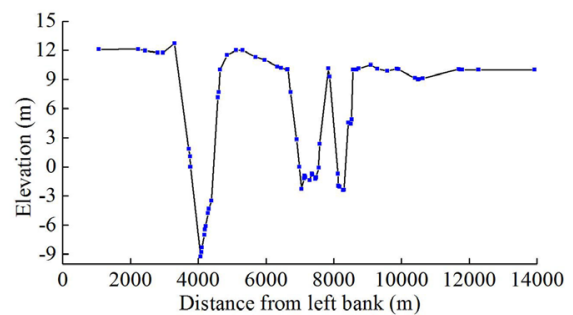

(c)

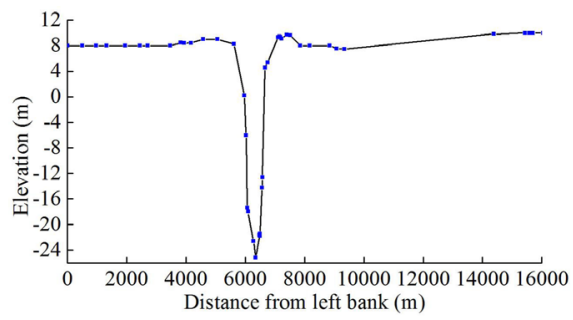

(b)

Figure 3. Typical transverse profile of the Mekong Delta. (a) Cro-section of Mekong River at Ta Meang, about $5.9 \mathrm{~km}$ below Kompong Cham Station; (b) Cro-section of Mekong River at Chheu Tea, about $81.3 \mathrm{~km}$ below Kompong Cham Station; (c) Cro-section of Mekong River at Puk Ruessei Kraom, about 92.6 km below Kompong Cham Station.

bed drop of them is about $0.038 \%$ and $0.033 \%$, respectively. The deep vertical section of the mainstream of the Mekong River is shown in Figure 4. It can be seen the longitudinal profile of the riverbed in each river section is very different, showing several apparent twists and turns.

\subsubsection{Morphological Characteristics of Tonle Sap Lake Basin}

\section{1) Topographic features}

The mainstream of the Mekong River is connected to the Tonle Sap Lake, Southeast Asia's largest freshwater lake, through the 148-km Tonle Sap River in Phnom Penh. The western junction of the Tonle Sap Lake basin is the Elephant Mountains and the Cardamom Mountains. The southwest narrowed to the Gulf of Thailand, and the northern part is the Dângrêk Mountains which separated Tonle Sap Lake basin from the Khorat Plateau. Tonle Sap Lake basin has a drainage area of $86,000 \mathrm{~km}^{2}$, including $81,700 \mathrm{~km}^{2}$ in Cambodia. The west, north, and east parts of Tonle Sap Lake basin are mountainous area with the terrain higher than $50 \mathrm{~m}$ above sea level, accounting for $54 \%$ of the Tonle Sap Lake basin. The Cardamom Mountains in the southwest are over $1700 \mathrm{~m}$ above sea level, and the Dângrêk Mountains in the north are $500 \mathrm{~m}$ above sea level. The central and southern parts are plain areas with low elevations, altitudes below $50 \mathrm{~m}$, and gentle slopes. The plain region accounts for $54 \%$ of total area of Tonle Sap Lake basin. The floodplain with a height of less than $11 \mathrm{~m}$ is about $1.62 \mathrm{~km}^{2}$, accounting for 19\% of Tonle Sap Lake's watershed area. The topographic distribution of the Tonle Sap Lake basin is shown in Figure 5.

The area and volume transition of Tonle Sap Lake at different water levels is flat, as shown in Figure 6, further illustrating the flat terrain of the Tonle Sap Lake Area. 


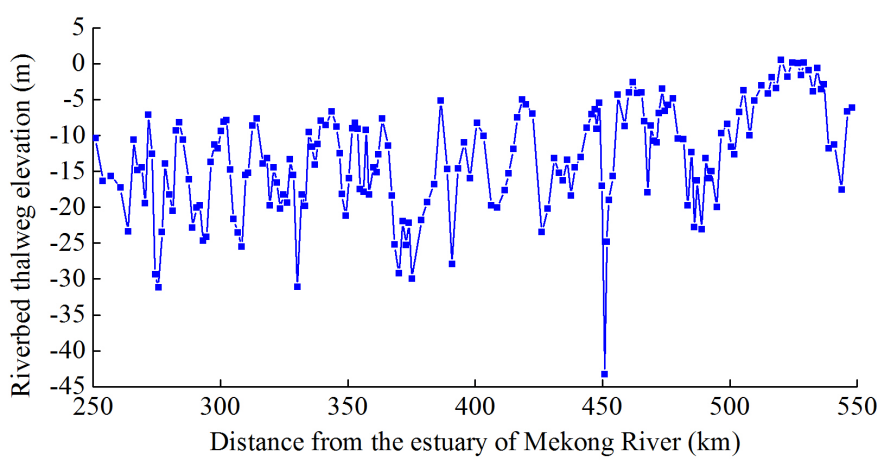

Figure 4. Typical transverse profile of the Mekong Delta.

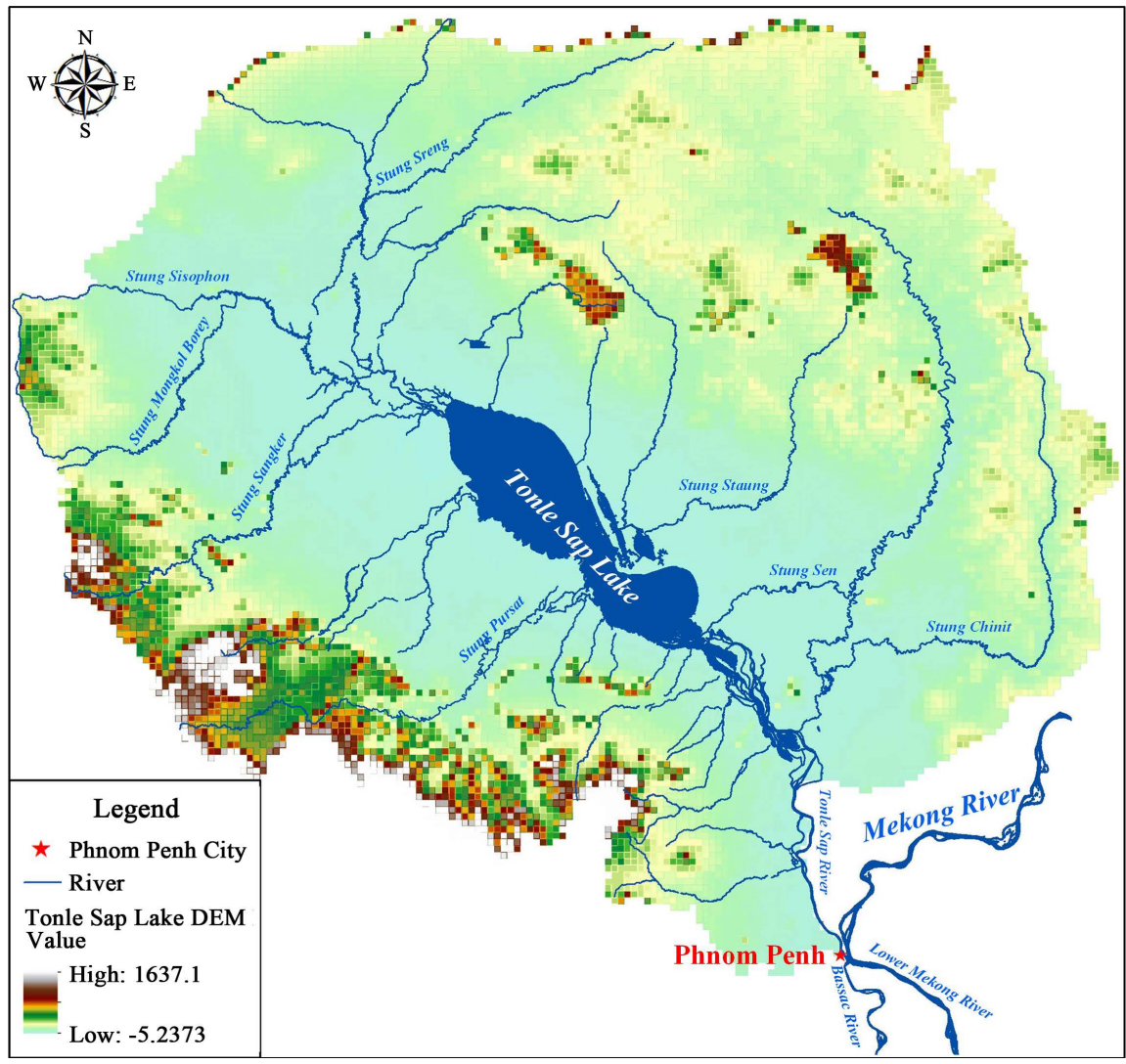

Figure 5. Topographic elevation of Tonle Sap Lake basin.

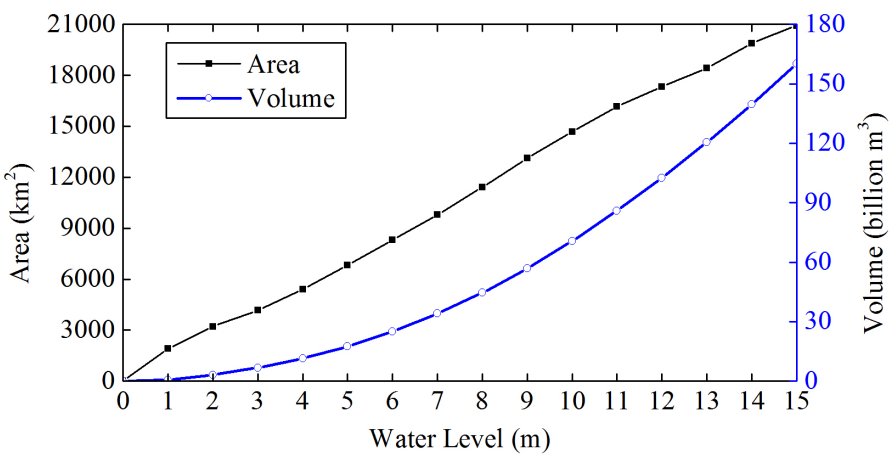

Figure 6. Water level-area (volume) curve of Tonle Sap lake. 


\section{2) Planform morphology}

The Tonle Sap Lake basin consists of Tonle Sap Lake, Tonle Sap River, 15 tributaries and floodplains. Among them, the branches with a catchment area of over $5000 \mathrm{~km}^{2}$ are Stung Sen, Stung Sreng, Stung Chinit, Stung Sangker, Stung Pursat, Stung Sisophon and Stung Mongkol Borey. According to the Tonle Sap Lake Area topographic map, when the water level of Tonle Sap Lake is $10 \mathrm{~m}$ at Kampong Luong, the lake is $350 \mathrm{~km}$ long, the largest lake width is $89 \mathrm{~km}$, and the smallest lake width is $12 \mathrm{~km}$, with the corresponding area of $13,111.38 \mathrm{~km}^{2}$ and volume of 56.73 billion $\mathrm{m}^{3}$, as shown in Figure 7 .

3) Cross section morphology

In the upper reaches of the Tonle Sap River at Samraong $(20 \mathrm{~km}$ from the Tonle Sap outlet), the morphology phenomenon of lacustrine facies under high water level and fluviatile facies under low water level is apparent. While the water level is below $7 \mathrm{~m}$, the water flow belongs to the deep trough, the average river width is about $1640 \mathrm{~m}$, and the average river bottom elevation is about -8.9 $\mathrm{m}$; when the water level is higher than $8 \mathrm{~m}$, the water flows up to the beach, and the river width increases rapidly; when the water level is $10 \mathrm{~m}$, the average river width reaches $16 \mathrm{~km}$. The cross-section of Phnom Penh Port $(1 \mathrm{~km}$ from the Tonle Sap outlet) and the Prek Kdam station (32 km from the Tonle Sap outlet), the Kampong Chhnang station (102.5 $\mathrm{km}$ from the Tonle Sap outlet), and the Kampong Luong station (171.76 km from the Tonle Sap estuary) are shown in Figure 8.

4) Longitudinal profile morphology

The lengths of the trail channel of Tonle Sap Lake, Tonle Sap Lake, and Tonle Sap River are about $90 \mathrm{~km}, 130 \mathrm{~km}$, and $129 \mathrm{~km}$ respectively. The average river channel drops of them are $0.0988 \%, 0.0024 \%$, and $0.0354 \%$, respectively. The thalweg cross-section of the riverbed is shown in Figure 9. It can be seen the

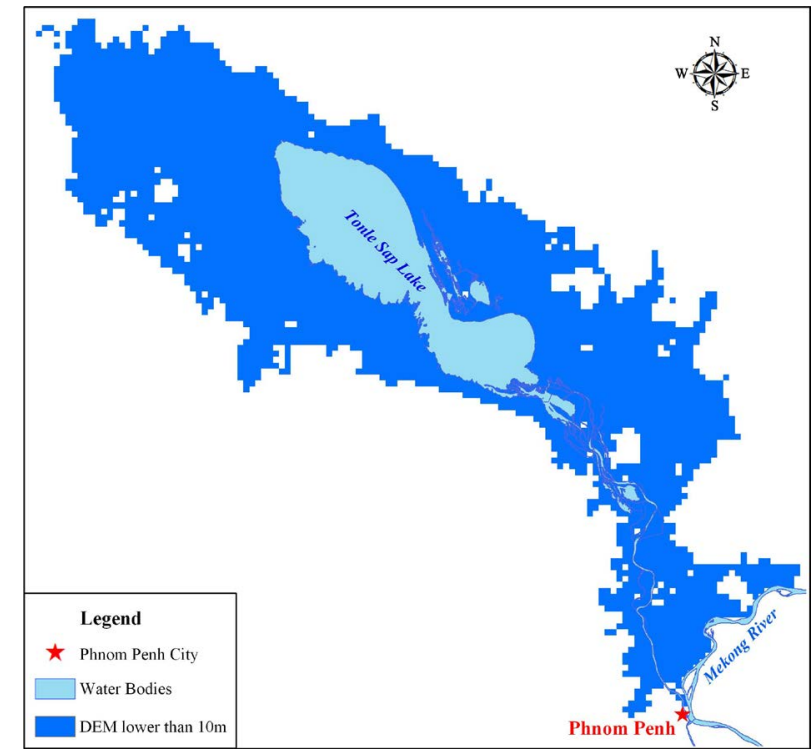

Figure 7. Distribution map of lake surface at the water level of $10 \mathrm{~m}$ in the Tonle Sap Lake. 


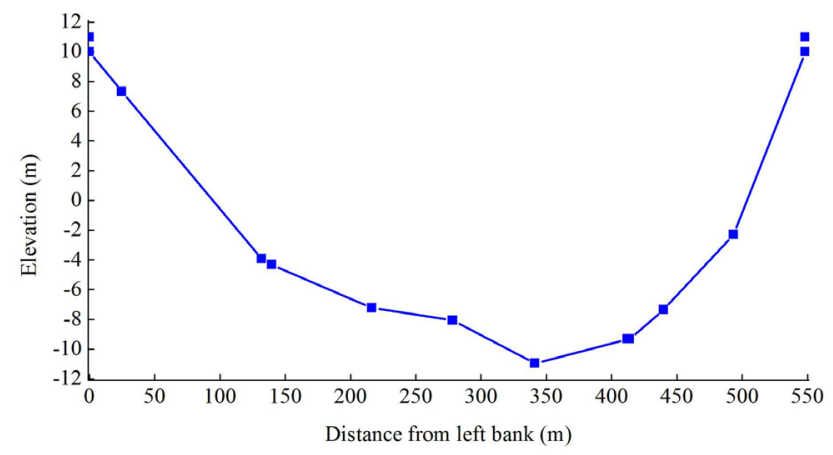

(a)

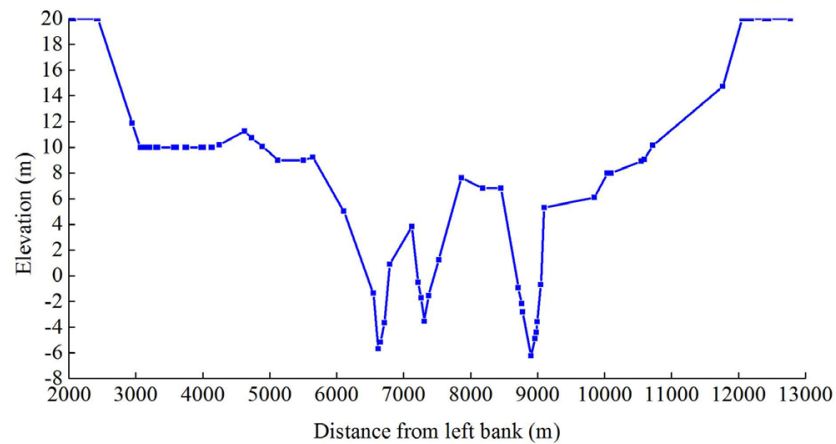

(c)

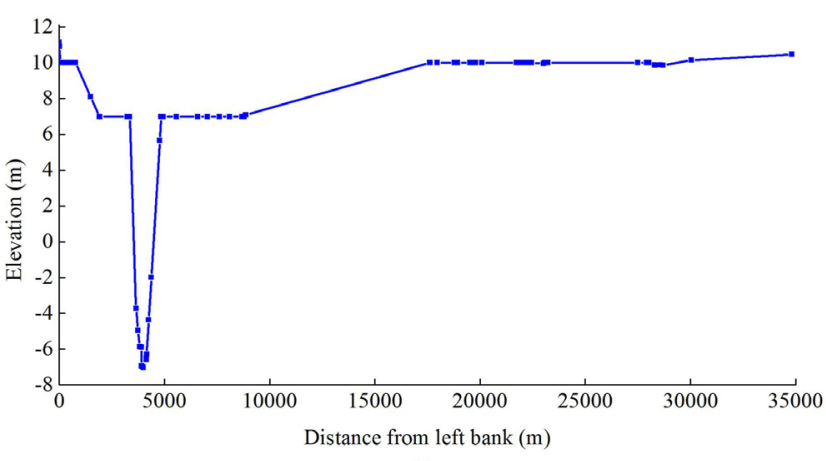

(b)

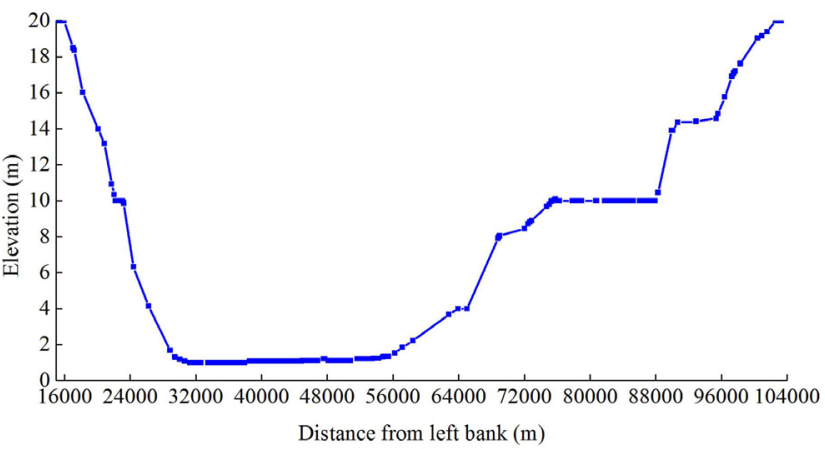

(d)

Figure 8. Typical cross-section of Tonle Sap Lake. (a) Cross-section of Phnh Port Station; (b) Cross-section of Prek Kdam Station; (c) Cross-section of Kampong Chhnang Station; (d) Cross-section of Kampong Luong Station.

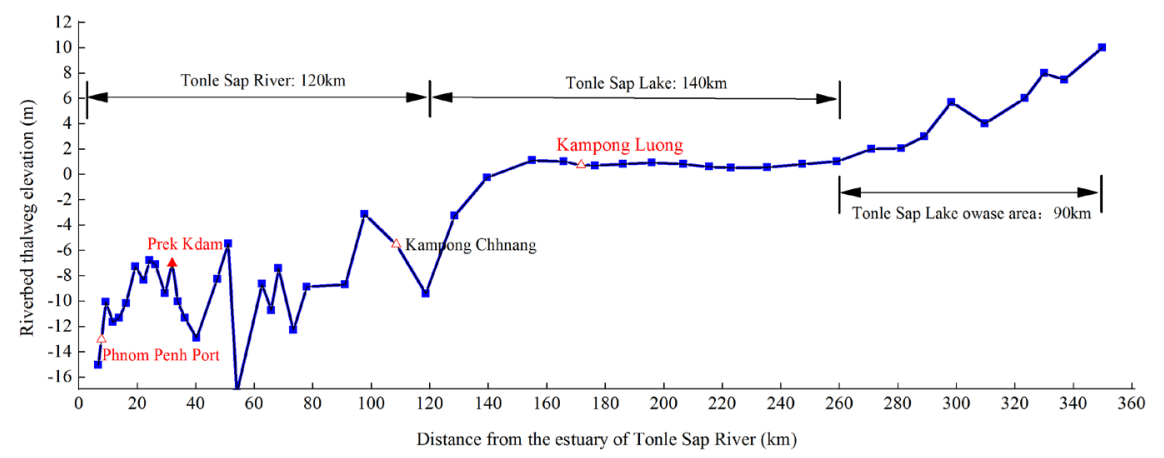

Figure 9. Thalweg vertical section of the river bed in the Tonle Sap Lake Area.

Tonle Sap Lake bed is relatively flat, and the riverbed longitudinal sections of the Tonle Sap River are very different, showing several distinct twists and turns.

\subsection{Hydrological Data and Processing}

\subsubsection{Distribution of the Hydrology Stations and Water-Level Stations in the Researched Reaches}

The Mekong River and Tonle Sap Lake meet in Phnom Penh, the capital of Cambodia, and then diverted into the Lower Mekong River and the Bassac River downstream of Phnom Penh. The distribution map of hydrological and water-level stations of the Mekong River, Tonle Sap Lake, and Tonle Sap River in the researched reaches is shown in Figure 10. 


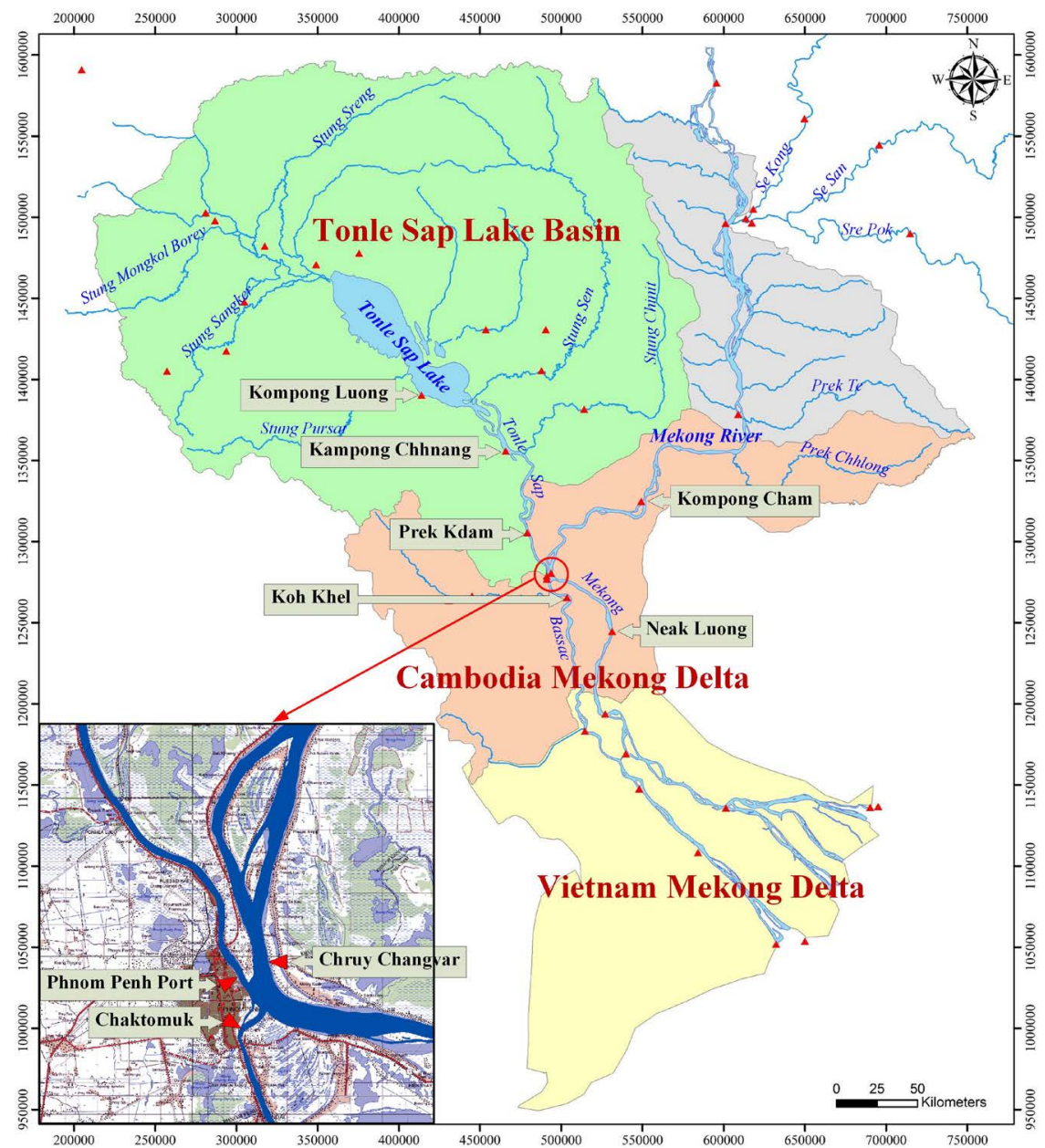

Figure 10. Distribution map of hydrology \& water level stations in the researched reaches.

The Mekong River has three hydrological stations: Kampong Cham, Chruy Changvar and Neak Luong. Bassac River has two hydrological stations: Chaktomuk and Koh Khel. Also, the catchment area of Kampong Cham Station is $660,000 \mathrm{~km}^{2}$, with the distance of around $103 \mathrm{~km}$ from the exit of Tonle Sap River in Phnom Penh, and the distance of about $448 \mathrm{~km}$ from the estuary. Additionally, the catchment area of Chruy Changvar Station is $663,000 \mathrm{~km}^{2}$, with the distance of approximately $2 \mathrm{~km}$ from the exit of Tonle Sap River. The distance of Neak Luong station and Chaktomuk station from the estuary is $227 \mathrm{~km}$ and around $325 \mathrm{~km}$, respectively, and Koh Khel station is $9 \mathrm{~km}$ downstream of Chaktomuk station.

Tonle Sap Lake Area has 2 water-level stations, including Kampong Chhnang and Kampong Luong. Among them, Kampong Chhnang Station is about $109 \mathrm{~km}$ from Mekong River, and Kampong Luong Station is about $172 \mathrm{~km}$ from Mekong River.

Tonle Sap River is the connecting river between Tonle Sap Lake and the Mekong River. The Tonle Sap River has two stations, Phnom Penh Port and Prek Kdam. The Prek Kdam station is a hydrological station and the Phnom Penh 


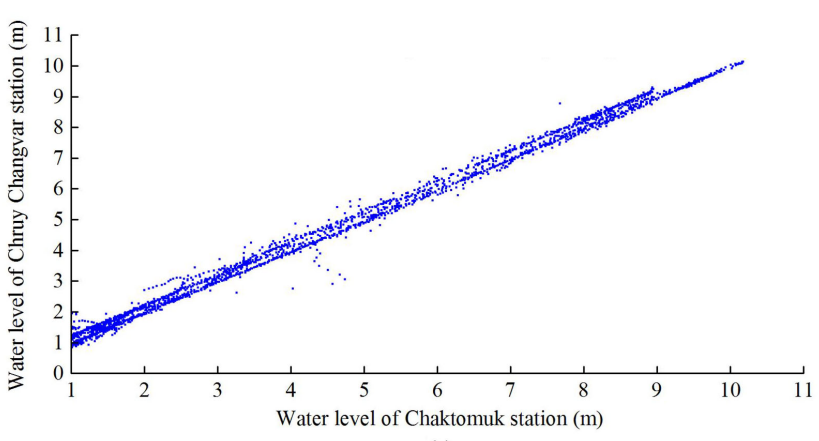

(a)
Port is a water-level station. The Phnom Penh Port station is located at the end of the Tonle Sap River exit section, about $1 \mathrm{~km}$ from the exit; Prek Kdam station is the flow controlling station of Tonle Sap Lake, about $32 \mathrm{~km}$ from the exit of Tonle Sap River.

\subsubsection{Selection of River-Lake Controlling Stations and Hydrological Data}

1) Selection of river-lake controlling station

The Kampong Cham station in the mainstream of the Mekong River controls the inflow of more than $81 \%$ of the catchment area of the whole basin, and there are few tributaries between Kampong Cham and Phnom Penh, the exit of the Tonle Sap Lake. The Mekong River is divided into the Bassac River and the lower Mekong River below Phnom Penh. Kok Khel station controls the inflow of Bassac River, and Neak Luong hydrological station controls the inflow of lower Mekong River. Kampong Cham, Neak Luong, and Koh Khel Stations were used as the water level and flow standing stations of the Mekong River.

There are three stations at the exit of Tonle Sap River in Phnom Penh, Chruy Changvar, Phnom Penh Port and Chaktomuk. These three stations are very close to each other on three rivers. Among them, Chruy Changvar Station is located in the lower Mekong River and $2 \mathrm{~km}$ upstream of the exit of Tonle Sap River, Phnom Penh Port Station is located at the end of the Tonle Sap River, Chaktomuk Station is located in the Bassac River and about $20 \mathrm{~km}$ downstream of the exit of Tonle Sap River, and the location relationship of them is shown in Figure 10.

The water level relationship is shown in Figure 11. It can be seen that: the water levels of Phnom Penh Port station, Chruy Changvar station and Chaktomuk station are strictly linearly related. Considering that the water level data series of Chaktomuk station is longer than the other two stations, so the Chaktomuk Station was used as the water level representative station at the intersection of the Mekong River and the Tonle Sap River.

Kampong Chhnang station of Tonle Sap Lake Area is located at the intersection of Tonle Sap Lake and Tonle Sap River, so its water level cannot be representative for Tonle Sap Lake and Tonle Sap River. Meanwhile, its vertical datum

Figure 11. Water level correlation relationship among Tonle Sap River (Phnom Penh Port station), Mekong River (Chruy Changvar station) and Bassac River (Chaktomuk station) at Phnom Penh. (a) Water level correlation relationship between Chruy Changvar and Chaktomuk; (b) Water level correlation relationship between Phnom Penh Port and Chaktomuk. 
is not related to the Cambodian National Elevation Datum (M.S.L. Hatein datum). Therefore, this study selected Kampong Luong Station as the water level representative station of Tonle Sap Lake, and Prek Kdam Station as the water level and flow representative station of Tonle Sap River.

2) Selection of hydrological data

To ensure the consistency of hydrological analysis, the same hydrological data series from 1999 to 2011 of the six river-lake controlling stations selected above were used. Among them, the daily water level data of the Kampong Cham station in the mainstream of the Mekong River is used to analyze the water level characteristics of the Mekong River before the convergence of the Mekong River and the Tonle Sap Lake, and the flow data is used to analyze the inflow characteristics of the Mekong River. The daily water level data of the Chaktomuk station is used to analyze the water level characteristics in the confluence section of the Mekong River and the Tonle Sap Lake. The daily water level data of Kampong Luong station is used to statistically analyze the water level characteristics of Tonle Sap Lake. The water level of 6 station all adopts the Cambodian National Elevation Datum (M.S.L. Hatein datum).

\subsubsection{Water Level Characteristics of the Mekong River}

1) Inter-annual variation

According to the measured daily water level data from 1999 to 2011 of Kampong Cham, Chaktomuk, Neak Luong and Koh Khel stations, the average annual water level, annual maximum water level, and annual minimum water level were counted. The statistical results are shown in Table 1.

The average water level of the four stations was $6.20 \mathrm{~m}, 4.14 \mathrm{~m}, 3.30 \mathrm{~m}$, and $3.39 \mathrm{~m}$, respectively. The highest water levels were $15.16 \mathrm{~m}, 10.18 \mathrm{~m}, 7.79 \mathrm{~m}$, and $6.94 \mathrm{~m}$ respectively. The highest water level of Kampong Cham station before the river-lake convergence occurred in 2001. The highest water level of Chaktomuk station in the confluence section of the Mekong River and Tonle Sap Lake and the Neak Luong and Koh Khel stations after the confluence of Mekong River and Tonle Sap Lake occurred in 2000. The lowest water levels in the past years were $1.02 \mathrm{~m}, 0.33 \mathrm{~m}, 0.52 \mathrm{~m}$, and $0.46 \mathrm{~m}$ respectively, of which Kampong Cham station occurred in 1999, Chaktomuk, Neak Luong and Koh Khel stations occurred in 2005. It can be seen that: after the adjustment function of Tonle Sap Lake on the inflow of Mekong River, the Phnom Penh reach and downstream reaches of Mekong River has similar water level characteristics. With the increasing capacity of the floodplain, the average annual water level amplitude of variation of Kampong Cham, Chaktomuk, Neak Luong and Koh Khel decreased by $2.59 \mathrm{~m}, 2.27 \mathrm{~m}, 1.56 \mathrm{~m}$, and $1.40 \mathrm{~m}$ respectively.

2) Annual variation

The flood season in the Mekong Delta is from June to November, and the dry season is from December to May. The highest water level occurs in September, and the lowest water level occurs in April, as shown in Figure 12. 
Table 1. Inter-annual variation characteristics of water level in the Mekong River.

\begin{tabular}{|c|c|c|c|c|c|c|c|c|c|c|c|c|}
\hline \multirow[b]{2}{*}{ Year } & \multicolumn{4}{|c|}{ Annual average water level (m) } & \multicolumn{4}{|c|}{ Annual highest water level (m) } & \multicolumn{4}{|c|}{ Annual lowest water level (m) } \\
\hline & $\begin{array}{c}\text { Kampong } \\
\text { Cham }\end{array}$ & Chaktomuk & $\begin{array}{l}\text { Neak } \\
\text { Luong }\end{array}$ & $\begin{array}{l}\text { Koh } \\
\text { Khel }\end{array}$ & $\begin{array}{c}\text { Kampong } \\
\text { Cham }\end{array}$ & Chaktomuk & $\begin{array}{l}\text { Neak } \\
\text { Luong }\end{array}$ & $\begin{array}{l}\text { Koh } \\
\text { Khel }\end{array}$ & $\begin{array}{c}\text { Kampong } \\
\text { Cham }\end{array}$ & Chaktomuk & $\begin{array}{l}\text { Neak } \\
\text { Luong }\end{array}$ & $\begin{array}{l}\text { Koh } \\
\text { Khel }\end{array}$ \\
\hline 1999 & 6.44 & 4.57 & 3.49 & 3.58 & 13.79 & 8.86 & 6.67 & 6.28 & 1.02 & 0.71 & 0.63 & 0.60 \\
\hline 2000 & 7.38 & 5.29 & 4.07 & 4.07 & 14.98 & 10.18 & 7.79 & 6.94 & 1.53 & 1.07 & 0.87 & 0.92 \\
\hline 2002 & 6.89 & 4.83 & 3.72 & 3.74 & 14.98 & 9.88 & 7.56 & 6.72 & 1.59 & 0.96 & 0.77 & 0.82 \\
\hline 2003 & 5.52 & 3.51 & 2.91 & 3.10 & 13.95 & 8.41 & 6.65 & 6.37 & 1.75 & 0.74 & 0.87 & 0.85 \\
\hline 2004 & 5.58 & 3.61 & 2.98 & 3.05 & 14.14 & 8.95 & 7.08 & 6.53 & 1.15 & 0.50 & 0.59 & 0.58 \\
\hline 2005 & 5.89 & 3.82 & 3.11 & 3.16 & 14.41 & 8.93 & 7 & 6.42 & 1.29 & 0.33 & 0.52 & 0.46 \\
\hline 2007 & 5.76 & 3.72 & 2.99 & 3.15 & 13.59 & 8.62 & 6.68 & 6.40 & 1.35 & 0.59 & 0.6 & 0.66 \\
\hline 2008 & 6.39 & 4.18 & 3.34 & 3.49 & 13.46 & 8.30 & 6.37 & 6.22 & 1.61 & 0.74 & 0.73 & 0.74 \\
\hline 2009 & 6.11 & 3.97 & 3.23 & 3.36 & 14.23 & 8.90 & 6.89 & 6.53 & 1.58 & 0.65 & 0.83 & 0.68 \\
\hline 2010 & 4.79 & 3.02 & 2.51 & 2.67 & 12.50 & 7.47 & 5.6 & 5.89 & 1.30 & 0.52 & 0.59 & 0.63 \\
\hline 2011 & 6.74 & 4.42 & 3.58 & 3.57 & 15.09 & 9.84 & 7.73 & 6.89 & 1.60 & 0.70 & 0.69 & 0.76 \\
\hline Average & 6.20 & 4.14 & 3.30 & 3.39 & 14.18 & 9.00 & 6.95 & 6.49 & 1.46 & 0.70 & 0.71 & 0.71 \\
\hline Highest & 7.38 & 5.29 & 4.07 & 4.07 & 15.16 & 10.18 & 7.79 & 6.94 & 1.75 & 1.07 & 0.87 & 0.92 \\
\hline Lowest & 4.79 & 3.02 & 2.51 & 2.67 & 12.5 & 7.47 & 5.60 & 5.89 & 1.02 & 0.33 & 0.52 & 0.46 \\
\hline Range & 2.59 & 2.27 & 1.56 & 1.40 & 2.66 & 2.71 & 2.19 & 1.05 & 0.73 & 0.74 & 0.35 & 0.46 \\
\hline
\end{tabular}

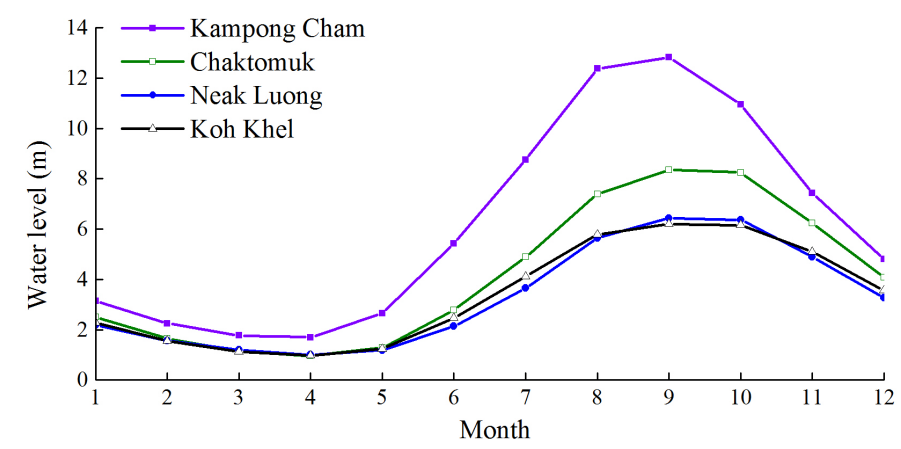

Figure 12. Monthly average water level distribution of main control stations in the Mekong Delta.

The average water levels of Kampong Cham, Chaktomuk, Neak Luong and Koh Khel in September are $12.83 \mathrm{~m}, 8.35 \mathrm{~m}, 6.43 \mathrm{~m}$, and $6.20 \mathrm{~m}$, respectively, and the water level amplitudes are $3.36 \mathrm{~m}, 3.24 \mathrm{~m}, 2.51 \mathrm{~m}$, and $1.26 \mathrm{~m}$ respectively. The average water levels of Kampong Cham, Chaktomuk, Neak Luong and Koh Khel in April are $1.70 \mathrm{~m}, 0.96 \mathrm{~m}, 1.00 \mathrm{~m}$, and $0.97 \mathrm{~m}$, respectively, and the water level amplitudes are $0.66 \mathrm{~m}, 0.69 \mathrm{~m}, 0.38 \mathrm{~m}$, and $0.43 \mathrm{~m}$, respectively.

\subsubsection{Water Level Characteristics of Tonle Sap Lake Area}

1) Inter-annual variation 
According to the measured daily water level data from 1999 to 2011 of the Prek Kdam station in Tonle Sap River and the Kampong Luong station in Tonle Sap Lake, the average annual water level, the yearly maximum and minimum water level are counted. The statistical results are shown in Table 2. It can be seen the average water level of the two stations is $4.49 \mathrm{~m}$ and $4.82 \mathrm{~m}$, respectively. The highest water levels are $10.38 \mathrm{~m}$ in 2000 and $10.54 \mathrm{~m}$ in 2011 . The lowest water levels are $0.71 \mathrm{~m}$ in 1999 and $1.11 \mathrm{~m}$ in 2010, respectively. Tonle Sap River and Mekong River have similar water level characteristics. Affected by the inflow of Tonle Sap Lake watershed and Mekong River, the water level characteristic of Tonle Sap Lake is different from that of the Mekong River.

2) Annual variation

The monthly average water level distribution at Prek Kdam and Kampong Luong stations in Tonle Sap Lake Area is shown in Figure 13.

It can see that the highest water level of both stations occurred in October, the average water level of this month was $8.72 \mathrm{~m}$ and $9.00 \mathrm{~m}$, respectively, and the water level variation range was $2.88 \mathrm{~m}$ and $3.00 \mathrm{~m}$ respectively. The lowest water level occurred in April and May respectively, the average water level is $1.16 \mathrm{~m}$ and $1.57 \mathrm{~m}$, respectively, and the water level variation range is $0.39 \mathrm{~m}$ and $0.74 \mathrm{~m}$,

Table 2. Inter-annual variation characteristics of water level in the Tonle Sap Lake Area.

\begin{tabular}{|c|c|c|c|c|c|c|}
\hline \multirow{2}{*}{ Year } & \multicolumn{2}{|c|}{$\begin{array}{l}\text { Annual average } \\
\text { water level (m) }\end{array}$} & \multicolumn{2}{|c|}{$\begin{array}{l}\text { Annual highest } \\
\text { water level (m) }\end{array}$} & \multicolumn{2}{|c|}{$\begin{array}{l}\text { Annual lowest } \\
\text { water level (m) }\end{array}$} \\
\hline & $\begin{array}{c}\text { Prek } \\
\text { Kdam }\end{array}$ & $\begin{array}{l}\text { Kampong } \\
\text { Luong }\end{array}$ & $\begin{array}{c}\text { Prek } \\
\text { Kdam }\end{array}$ & $\begin{array}{c}\text { Kampong } \\
\text { Luong }\end{array}$ & $\begin{array}{c}\text { Prek } \\
\text { Kdam }\end{array}$ & $\begin{array}{c}\text { Kampong } \\
\text { Luong }\end{array}$ \\
\hline 1999 & 4.73 & 4.98 & 8.89 & 8.97 & 0.71 & 1.24 \\
\hline 2000 & 5.61 & 5.83 & 10.38 & 10.36 & 1.10 & 1.71 \\
\hline 2001 & 5.25 & 5.52 & 9.86 & 9.89 & 1.10 & 1.42 \\
\hline 2002 & 5.02 & 5.26 & 10.00 & 10.10 & 1.11 & 1.19 \\
\hline 2003 & 3.92 & 4.47 & 8.41 & 8.26 & 1.10 & 1.36 \\
\hline 2004 & 4.01 & 4.29 & 9.17 & 9.20 & 1.10 & 1.25 \\
\hline 2005 & 4.20 & 4.70 & 9.26 & 9.29 & 0.72 & 1.26 \\
\hline 2006 & 4.32 & 4.61 & 9.15 & 9.20 & 0.83 & 1.25 \\
\hline 2007 & 4.10 & 4.42 & 8.85 & 8.99 & 0.78 & 1.34 \\
\hline 2008 & 4.56 & 4.89 & 8.61 & 8.70 & 1.11 & 1.29 \\
\hline 2009 & 4.45 & 4.96 & 9.13 & 9.23 & 0.92 & 1.78 \\
\hline 2010 & 3.39 & 3.72 & 7.66 & 7.73 & 0.75 & 1.11 \\
\hline 2011 & 4.87 & 5.04 & 10.27 & 10.54 & 1.00 & 1.27 \\
\hline Average & 4.49 & 4.82 & 9.20 & 9.27 & 0.95 & 1.34 \\
\hline Highest & 5.61 & 5.83 & 10.38 & 10.54 & 1.11 & 1.78 \\
\hline Lowest & 3.39 & 3.72 & 7.66 & 7.73 & 0.71 & 1.11 \\
\hline Range & 2.22 & 2.11 & 2.72 & 2.81 & 0.40 & 0.67 \\
\hline
\end{tabular}




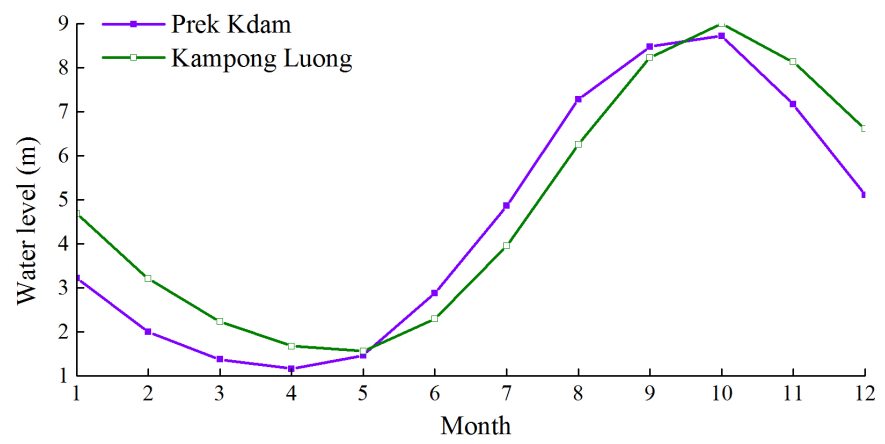

Figure 13. Monthly average water level distribution of main control stations in Tonle Sap Lake Area.

respectively. Besides, the water level fluctuation process of the two stations in Tonle Sap Lake Area is consistent. From May to September, the water levels from the bottom to the top of Prek Kdam and Kampong Luong decreased accordingly. Meanwhile, the water level of the Mekong River was higher than that of Tonle Sap Lake, which caused the flood of the Mekong River reverse flow to the Tonle Sap Lake. After the flood season from October to April, the water level of the Mekong River is lower than that of Tonle Sap Lake, which makes the water of Tonle Sap Lake flow out to the Mekong River. During the highest water level period from the end of September to the beginning of October, the water levels of the two stations are in the same, reflecting the river-lake relationship between the Mekong River and the Tonle Sap Lake.

\section{Results and Discussion}

\subsection{Response Relationship of River-Lake Water Level Characteristics to Morphological Features}

Kampong Cham Station is used as the hydrological representative station of Mekong River upstream Phnom Penh. Neak Luong and Koh Khel are the hydrological representative stations of the Mekong River downstream Phnom Penh. The Chaktomuk Station is the water level representative station at the intersection of the Mekong River and the Tonle Sap River. Prek Kdam Station is the hydrological representative station of Tonle Sap River, and Kampong Luong Station is the water level representative station of Tonle Sap Lake. Based on long series of hydrological data of river-lake controlling station, the water level variation characteristics of the Mekong River and Tonle Sap Lake and their response to the morphological characteristics of them were analyzed.

\subsubsection{Response Relationship of the Water Level Fluctuation of Mekong River to the River-Lake Morphological Characteristics}

The Mekong Delta is a flat, silt-type river with a small stream gradient. Affected by the regulation of floodplain of the Mekong Delta and the Tonle Sap Lake, the water surface ratio tends to be gentle. The average water surface ratio of the Kampong Cham to Chaktomuk section of the Mekong River is $0.0198 \%$, far less than the average river channel ratio of $0.038 \%$; the average water surface ratio of 
the Chaktomuk to Koh Khel section of Bassac River is $0.0198 \%$, which is less than the average channel ratio of $0.033 \%$.

Due to large catchment area, abundant precipitation, small stream gradient, large storage capacity of river channel, flood plain and lake, the flood process of Mekong River is characterized by high peak, large volume, long duration, flat peak shape and slow fluctuation. Taking the year 2000 as an example, the floodplain area of the Mekong Delta is increasing along the river. The area of the floodplain above the Kampong Cham section, the Chaktomuk section (including the Tonle Sap Lake) and the Cambodian-Vietnamese border section is about $1322 \mathrm{~km}^{2}$ and $20,148 \mathrm{~km}^{2}$ and $25,909 \mathrm{~km}^{2}$, respectively. Correspondingly, the water level fluctuation along the course tends to be gentle, and the ratio of the water withdrawal days to the water increases days decreases from 1.73 in the Kampong Cham section to 1.60 in the Phnom Penh section and 1.54 in the Koh Khel section. The annual average daily water rising rate decreases from $0.16 \mathrm{~m} / \mathrm{d}$ in the Kampong Cham section to $0.09 \mathrm{~m} / \mathrm{d}$ in the Phnom Penh section and 0.07 $\mathrm{m} / \mathrm{d}$ in the Koh Khel section. The annual average daily water withdrawalling rate is reduced from $0.09 \mathrm{~m} / \mathrm{d}$ in the Kampong Cham section to $0.06 \mathrm{~m} / \mathrm{d}$ in the Phnom Penh section and $0.05 \mathrm{~m} / \mathrm{d}$ in the Koh Khel section. The annual average daily water level rising and falling rate are basically in a single linear relationship with the floodplain area, as shown in Figure 14, which indicates that the water level fluctuation positively correlated with the floodplain storage area, and the water increase is greater than the water withdrawal.

\subsubsection{Response Relationship of the Overland Flood of Mekong River to the River-Lake Morphological Characteristics}

Compared with the upstream inflow, Cambodia Mekong Delta does not have adequate channel storage capacity. When the upstream inflow is large, vast flooding plain of left and right banks are easily inundated, and the flood relations of two banks become complicated. The elevation of the left and right banks of the Mekong River and the water surface line of the 5-year return period are shown in Figure 15. It can be seen that the elevations on both sides of most river sections are below the 5-year return period water surface line and are highly vulnerable to flooding.

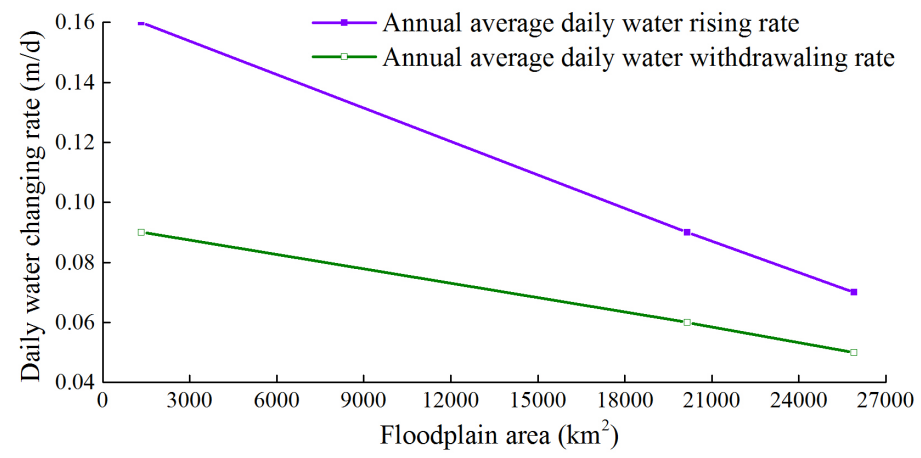

Figure 14. Correlation between the annual average daily water level rising and falling rate and the floodplain area in the Mekong Delta. 


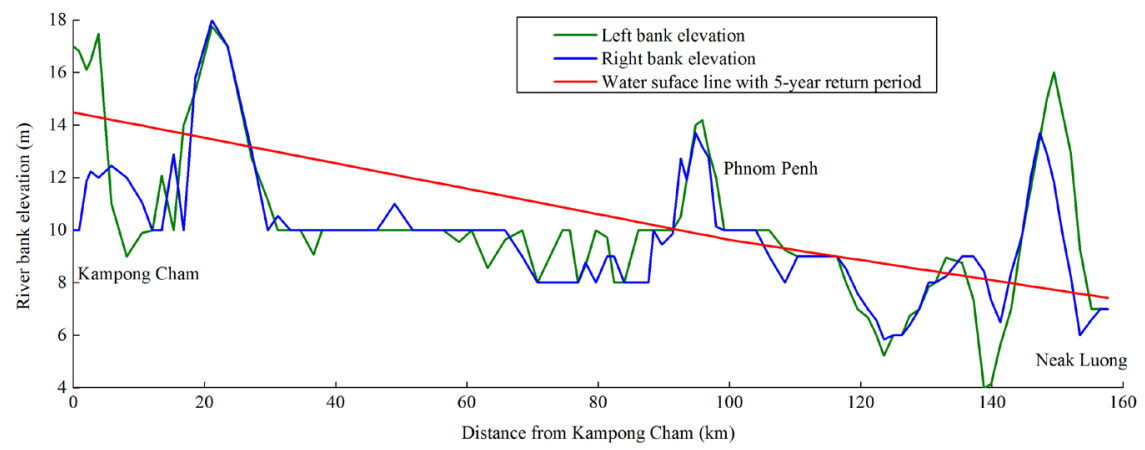

Figure 15. Elevation of left and right banks and water surface line with 5-year return period of the Kampong Cham-Neak Luong section of the Mekong River.

According to the flooding relationship between the left and right banks of the Mekong River, the Cambodian Mekong Delta is divided into Region 1 (Tonle Sap Lake), Region 2 (between the reaches upstream Phnom Penh on the right bank of the Mekong River and No. 6 National Road), Region 3 (right bank of Bassac River), and Region 4 (the right bank of the Mekong River and the left bank of the Bassac River) and Region 5 (the left bank of the Mekong River) [16]. In 2003, the distribution of floods from July to December in each region is shown in Figure 16.

It can be seen that there are 17.3 billion $\mathrm{m}^{3}$ of flood in the Kampong Cham to Phnom Penh section of the Mekong River entering the floodplain of the left bank, of which the sections upstream and downstream Phnom Penh have 1.1 billion $\mathrm{m}^{3}$ and 10.7 billion $\mathrm{m}^{3}$ of overbank flood finally return to the river channel, respectively; there are 8.9 billion $\mathrm{m}^{3}$ of flood into the right bank floodplain (Region 2), of which 1 billion $\mathrm{m}^{3}$ of overbank flood eventually returning to the Mekong River channel, 5.9 billion $\mathrm{m}^{3}$ and 2 billion $\mathrm{m}^{3}$ of overbank flood entered the Tonle Sap River and Tonle Sap Lake respectively; Phnom Penh to the Cambodia-Vietnam border section had 17.6 billion $\mathrm{m}^{3}$ of flood entering the floodplain, of which the overbank flood volume in Region 5, Region 4 and Region 3 are 4.2 billion $\mathrm{m}^{3}, 6.9$ billion $\mathrm{m}^{3}$, and 6.5 billion $\mathrm{m}^{3}$ respectively, and $95 \%$ of the overbank flood $\left(16.7\right.$ billion $\mathrm{m}^{3}$ ) flows directly into the Vietnam Mekong Delta, of which the overbank flood volume in Region 5, Region 4 and Region 3 are 7.9 billion $\mathrm{m}^{3}, 3.2$ billion $\mathrm{m}^{3}$, and 5.6 billion $\mathrm{m}^{3}$ respectively.

During the flood season, when the water level of the Kampong Cham station is higher $13 \mathrm{~m}$, or the discharge exceeds $25,000 \mathrm{~m}^{3} / \mathrm{s}$, and the water level of Chaktomuk is higher $8 \mathrm{~m}$, the flood begins to overflow on both sides of the Mekong River. Through large number of old river channels or silt channels, the overbank flood flows to the flood plain after the levee. The floods linger on the flat flood plains up to $50 \mathrm{~km}$ wide, flooding the vast floodplains for weeks [16] [20] [21] [22]. The estimated monthly overbank flood volume at Kampong Cham-Chaktomuk section of the Mekong River from 1995 to 2011 is shown in Figure 17. It can be seen the average overland flood volume of the river section is about 31.2 billion $\mathrm{m}^{3}$, accounting for $8.7 \%$ of the total volume at the Kampong 


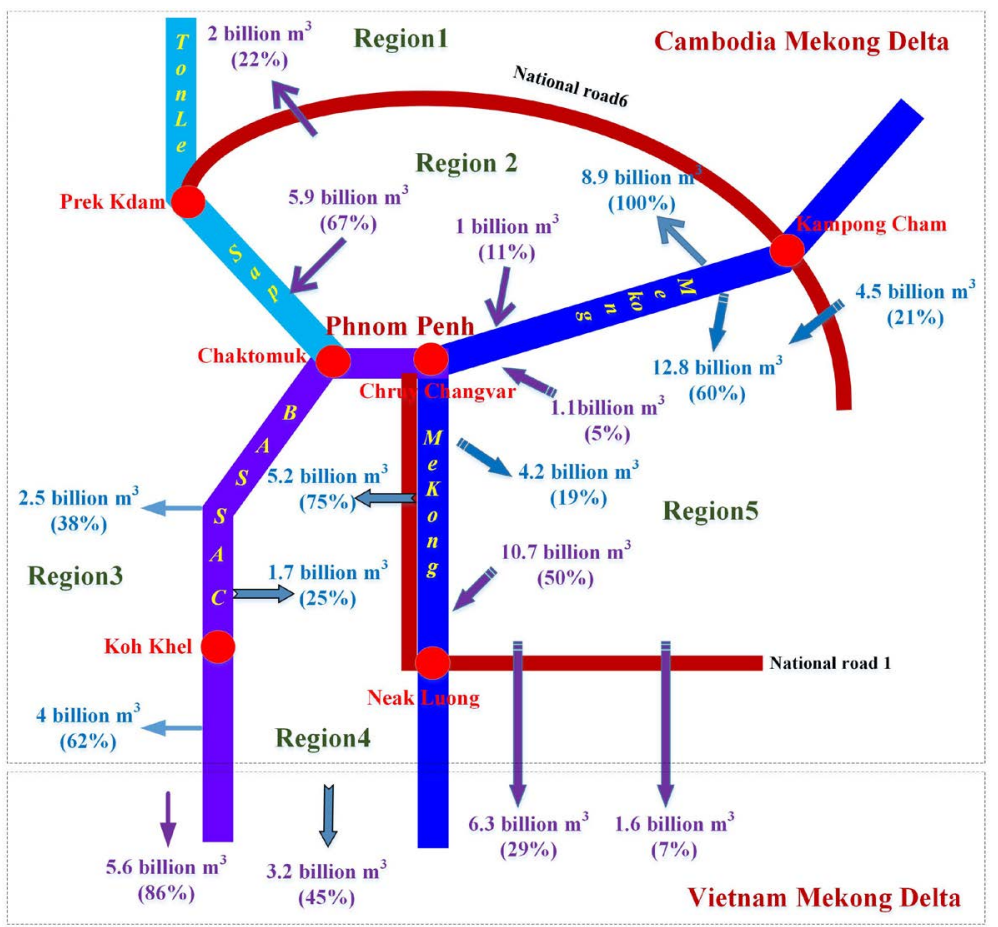

Figure 16. Flood volume distribution of the Cambodia floodplain from July to December, 2003.

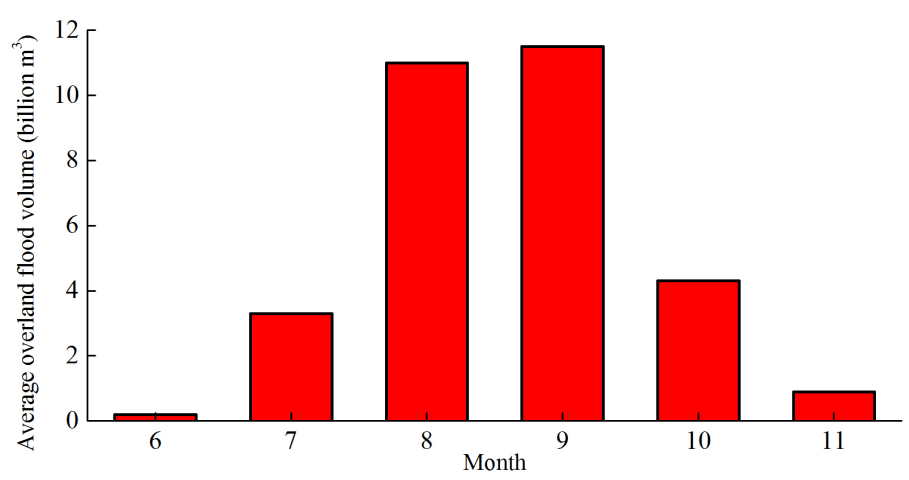

Figure 17. Multi-year average overbank flood volume at Kampong Cham-Chaktomuk section of the Mekong River.

Cham station. The overbank flood mainly concentrates from August to September, and the flood volume accounts for $65 \%$ - $72 \%$ of the total volume.

The daily flow of the Kampong Cham and Chruy Changvar stations in 2002 is shown in Figure 18. It can be seen when the flow of Kampong Cham station exceeds $25,000 \mathrm{~m}^{3} / \mathrm{s}$, the flood overflows the banks of the Mekong River at the Kampong Cham-Chruy Changvar section. The peak dicharge of Kampong Cham and Chruy Changvar stations in 2002 were 50,398 $\mathrm{m}^{3} / \mathrm{s}$ and $38,025 \mathrm{~m}^{3} / \mathrm{s}$ (occurred in August 24th) respectively, which reduced the flood peak of 12,373 $\mathrm{m}^{3} / \mathrm{s}$ for the Phnom Penh city through the flooding of the flood plains on both sides of the Kampong Cham-Chruy Changvar section, and the peak clipping rate is $24.55 \%$. The flood peak cutting ratio of the flood plains between the left and 


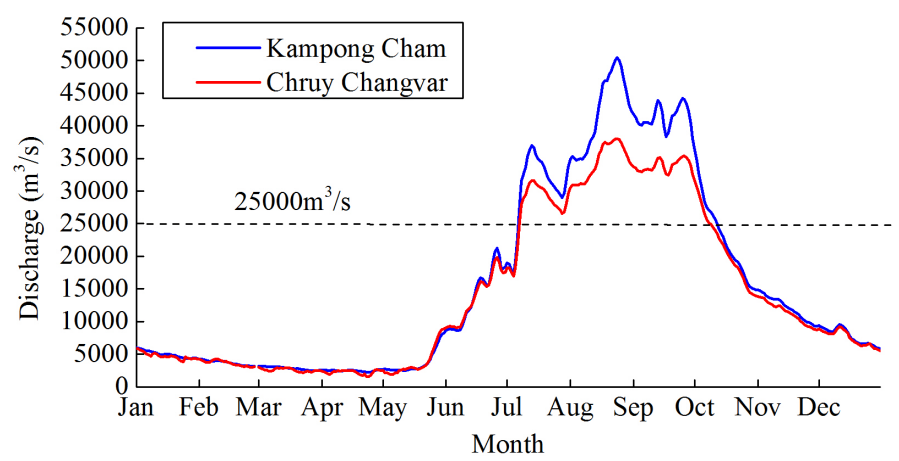

Figure 18. Daily flow process in Kampong Cham and Chruy Changvar in 2002.

right banks is 1.45:1, which reduces the flood peak flow by $5049 \mathrm{~m}^{3} / \mathrm{s}$ and 7324 $\mathrm{m}^{3} / \mathrm{s}$, the peak clipping rate is $10.02 \%$ and $14.53 \%$ [16]. The overbank flood volume at Kampong Cham-Chruy Changvar section is 50 billion $\mathrm{m}^{3}$ in 2002, accounting for $15.68 \%$ of Kampong Cham Station. The overbank flood volume ratio between the left and right banks is 1.125:1, that is, the overbank flood volume on the left and right banks are 23.5 billion $\mathrm{m}^{3}$ and 26.5 billion $\mathrm{m}^{3}$, respectively, accounting for $7.38 \%$ and $8.30 \%$ of Kampong Cham Station [20].

The floods in the lower reaches of Phnom Penh are affected by the storage and supplement function of Tonle Sap Lake. From 1995 to 2011, the average overbank flood volume was 5.4 billion $\mathrm{m}^{3}$, accounting for $1.6 \%$ of the total volume at the upstream Chruy Changvar station, of which the overbank flood volume was the most in July, about 2.6 billion $\mathrm{m}^{3}$.

\subsubsection{Response Relationship of Water Level Fluctuation to the Morphological Characteristics in Tonle Sap Lake Area}

Influenced by the floodplain of the Tonle Sap Lake Area, the average water surface slope of Kampong Luong-Prek Kdam section is $0.00598 \%$. Of which, the average water surface slope during the water-rising stage is $0.0057 \%$, and the maximum water surface slope is $0.048 \%$. During the water-falling stage, the average water surface slope is $0.0063 \%$, and the maximum water surface slope is $0.0181 \%$, which was much smaller than the average stream gradient of $0.0555 \%$.

After the adjustment of the Tonle Sap Lake, the water level in the Lake area fluctuated slowly. The ratio of water withdrawal days to the water increased days decreases from 1.48 at Prek Kdam Station to 1.19 at Kampong Luong Station. The average daily water level rising rate reduces from $0.08 \mathrm{~m} / \mathrm{d}$ at Prek Kdam Station to $0.06 \mathrm{~m} / \mathrm{d}$ at Kampong Luong Station, and the multi-year average daily water level withdrawalling rate reduces from $0.053 \mathrm{~m} / \mathrm{d}$ at Prek Kdam Station to $0.0459 \mathrm{~m} / \mathrm{d}$ at Kampong Luong Station.

According to the daily water level data from 1999 to 2011 of Kampong Luong Station in Tonle Sap Lake and the Tonle Sap Lake water level-area (volume) curve, the variation characteristics of water level, area, and volume of Tonle Sap Lake are analyzed, as shown in Table 3. 
Table 3. Variation characteristic values of water level, area, and volume in the Tonle Sap Lake.

\begin{tabular}{|c|c|c|c|c|c|c|c|c|c|c|c|c|}
\hline \multirow[b]{2}{*}{ Project } & \multicolumn{3}{|c|}{ Annual average } & \multicolumn{3}{|c|}{ Annual minimum value } & \multicolumn{3}{|c|}{ Annual maximum value } & \multicolumn{3}{|c|}{ Annual maximum variation } \\
\hline & $\begin{array}{c}\text { Water } \\
\text { level } \\
(\mathrm{m})\end{array}$ & $\begin{array}{l}\text { Area } \\
\left(\mathrm{km}^{2}\right)\end{array}$ & $\begin{array}{c}\text { Volume } \\
\text { (billion } \mathrm{m}^{3} \text { ) }\end{array}$ & $\begin{array}{c}\text { Water } \\
\text { level } \\
(\mathrm{m})\end{array}$ & $\begin{array}{l}\text { Area } \\
\left(\mathrm{km}^{2}\right)\end{array}$ & $\begin{array}{c}\text { Volume } \\
\left(\text { billion } \mathrm{m}^{3} \text { ) }\right.\end{array}$ & $\begin{array}{c}\text { Water } \\
\text { level } \\
(\mathrm{m})\end{array}$ & $\begin{array}{c}\text { Area } \\
\left(\mathrm{km}^{2}\right)\end{array}$ & $\begin{array}{c}\text { Volume } \\
\left(\text { billion } \mathrm{m}^{3}\right)\end{array}$ & $\begin{array}{c}\text { Water } \\
\text { level } \\
(\mathrm{m})\end{array}$ & $\begin{array}{l}\text { Area } \\
\left(\mathrm{km}^{2}\right)\end{array}$ & $\begin{array}{c}\text { Volume } \\
\left(\text { billion } \mathrm{m}^{3} \text { ) }\right.\end{array}$ \\
\hline $\begin{array}{l}\text { Multi-year } \\
\text { average }\end{array}$ & 4.82 & 6620 & 16.2 & 1.34 & 2361 & 1.3 & 9.27 & 13,458 & 60.8 & 7.92 & 11,097 & 59.5 \\
\hline $\begin{array}{l}\text { Multi-year } \\
\text { maximum }\end{array}$ & 5.83 & 8120 & 23.4 & 1.78 & 3076 & 2.4 & 10.54 & 15261 & 78.7 & 9.27 & 13028 & 77.6 \\
\hline $\begin{array}{l}\text { Multi-year } \\
\text { minimum }\end{array}$ & 3.72 & 5135 & 9.9 & 1.11 & 2053 & 0.8 & 7.73 & 11091 & 41.5 & 6.62 & 9038 & 40.8 \\
\hline
\end{tabular}

It can see that the area and volume of the Tonle Sap Lake during the flood and dry seasons are quite different. The average annual water level of Tonle Sap Lake is $4.82 \mathrm{~m}$, the corresponding lake area is $6620 \mathrm{~km}^{2}$, the volume is 16.2 billion $\mathrm{m}^{3}$; the measured maximum water level is $10.54 \mathrm{~m}$, the corresponding lake area is $15261 \mathrm{~km}^{2}$, and the volume is 78.7 billion $\mathrm{m}^{3}$; the measured minimum water level is $1.11 \mathrm{~m}$, the corresponding lake area is $2053 \mathrm{~km}^{2}$, and the volume is $800 \mathrm{mil}-$ lion $\mathrm{m}^{3}$. During the year, the minimum water level variation range is $6.62 \mathrm{~m}$, the corresponding area variation range is $9038 \mathrm{~km}^{2}$, and the water storage volume variation range is 40.8 billion $\mathrm{m}^{3}$. The maximum water level variation range during the year is $9.27 \mathrm{~m}$, the relevant lake area variation range is $13,028 \mathrm{~km}^{2}$, and the water storage capacity variation range is 77.6 billion $\mathrm{m}^{3}$. The multi-year average annual water level variation range is $7.92 \mathrm{~m}$, the relevant lake area variation range is $11,097 \mathrm{~km}^{2}$, and the water storage variation range is 59.5 billionm $^{3}$.

\subsection{Response Relationship of River-Lake Water Exchange Pattern to River-Lake Morphological Characteristics}

The water exchange pattern between Mekong River and Tonle Sap Lake and its response relationship to the river-lake morphological characteristics were studied. The water exchange intensity between the Mekong River and the Tonle Sap Lake is enormous, and the effect of peak cutting and water replenishing on the Mekong River runoff is noticeable, and the response relationship with the river-lake morphological characteristics is good.

\subsubsection{Exchange Pattern between the Mekong River and Tonle Sap Lake}

Tonle Sap Lake is the largest connected lake in the lower reaches of the Mekong River, with a drainage area of $86,000 \mathrm{~km}^{2}$, accounting for $10.6 \%$ of the area of the Mekong River. Tonle Sap Lake has a tremendous difference of area and volume between flood season and dry season. The average water level, area, and volume of Tonle Sap Lake increased from $1.51 \mathrm{~m}, 2487 \mathrm{~km}^{2}$, and 1.68 billion $\mathrm{m}^{3}$ in May to $8.70 \mathrm{~m}, 12,768 \mathrm{~km}^{2}$ and 52.88 billion $\mathrm{m}^{3}$ in October, respectively. Tonle Sap Lake has a substantial regulation effect on the Mekong River flood.

With the change of the water level between the Mekong River and the Tonle 
Sap Lake, the Mekong River reverse flow into the Tonle Sap Lake from the beginning of May to October, and the water of Tonle Sap Lake flow out to the Mekong River from the middle to late October to April in the next year. The water exchange intensity between the Mekong River and the Tonle Sap Lake is enormous, and the effect of peak cutting and water replenishing on the runoff of the Mekong River is visible. Taking the year 2000 to 2001 for example, the measured discharge of the Prek Kdam station is shown in Figure 19. It can be seen the Mekong River flood reverse flow to Tonle Sap Lake from May 16th to September 20th in 2000, and the reverse flow lasted 128 days. Tonle Sap Lake flow out to the Mekong River from September 21th in 2000 to May 18th in 2001, and water replenishing process lasted 240 days.

When the water level of the Mekong River is higher than the water level of Tonle Sap Lake, the flood of the Mekong River will reverse flow to Tonle Sap Lake. The reverse duration is long, and the reverse volume is significant. According to the flow data of the Prek Kdam station of Tonle Sap from 1999 to 2011 , the average annual reverse duration is 127 days, reverse volume is 39.7 billion $\mathrm{m}^{3}$, accounting for $14.4 \%$ of the runoff from the Kampong Cham station in the mainstream of the Mekong River. The average maximum daily reverse flow is $8618 \mathrm{~m}^{3} / \mathrm{s}$, and the average annual peak reduction rate of the Kampong Cham station in the Mekong River is $19.4 \%$. The peak flow of Kampong Cham station in the Mekong River is $44,526 \mathrm{~m}^{3} / \mathrm{s}$, and the reverse flow during the same period is $6857 \mathrm{~m}^{3} / \mathrm{s}$, so the average peak clipping rate is $15.6 \%$. The reverse volume of Mekong River reaches the highest in August, the average reverse volume is 16.7 billion $\mathrm{m}^{3}$, accounting for $17.7 \%$ of the runoff from the Kampong Cham station in the mainstream of the Mekong River. The average capacity of Tonle Sap Lake regulating the maximum $15 \mathrm{~d}, 60 \mathrm{~d}$ and $120 \mathrm{~d}$ flood volume of the Mekong River is $15 \%, 14 \%$ and $12 \%$, respectively, which significantly reduces the flood threats in the Cambodian capital of Phnom Penh and the downstream delta.

When the water level of Mekong River is lower than that of Tonle Sap Lake, Tonle Sap Lake will replenish water to Mekong River with a long duration and a large volume. According to the flow data of the Prek Kdam station of Tonle Sap River from 1999 to 2011, the average annual water replenishment duration is 238 days, and the amount of water replenished is 69.4 billion $\mathrm{m}^{3}$, accounting for $29.7 \%$

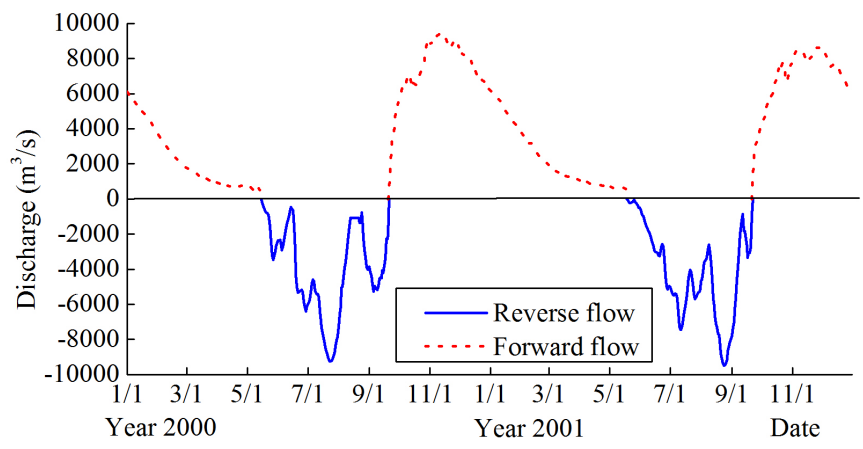

Figure 19. Daily flow of Prek Kdam station in 2000-2001. 
of the inflow in the lower reaches of Mekong River, which is 2.6 times as large as the area ratio, and 1.77 times as large as the reverse volume of Mekong River. The water replenishment mainly occurred from October to January, accounting for $83 \%$ of the total volume of the whole year.

In summary, Tonle Sap Lake is not only a vital buffer zone in the Mekong Delta but also can accommodate a large amount of flood in the upper reaches of the Mekong River during the rainy season, significantly reducing the flood threats in the lower reaches of the Mekong River. It can also serve as an important supplementary source of water during the dry season of the Mekong River, keeping the Mekong River adequate amount of water and water level to ensure the regular operation of navigation and downstream agricultural irrigation and prevent seawater intrusion in Vietnam Mekong Delta during the dry season.

\subsubsection{Response Relationship of River-Lake Water Exchange Pattern to River-Lake Morphological Characteristics}

Tonle Sap Lake has a relatively large lake area during the flood season compared to its narrow exit of Tonle Sap River. While the water level is low, the water flow resistance of the Tonle Sap Lake water flowing out to the Mekong River or the Mekong River flood flowing into the Tonle Sap Lake is relatively large compared to other parts of the lake area. The width of the Tonle Sap River is very different between low and high water levels, making the morphology phenomenon of lacustrine facies when the water level is high and fluviatile facies when the water level is low is apparent.

Take the Prek Kdam section as an example, while the water level is lower than $7 \mathrm{~m}$, and the water flow belongs to the deep trough. The river width corresponding to the water level of $1 \mathrm{~m}$ and $6 \mathrm{~m}$ is $1015 \mathrm{~m}$ and $1419 \mathrm{~m}$, respectively, increasing the river width for the unit river depth only $80.8 \mathrm{~m}$; the river channel section area corresponding to the water level of $1 \mathrm{~m}$ and $6 \mathrm{~m}$ are $5285 \mathrm{~m}^{2}$ and $11,374 \mathrm{~m}^{2}$, increasing the channel section area for the unit water depth only 1218 $\mathrm{m}^{2}$. When the water level is higher than $7 \mathrm{~m}$, the water flows out to the beach. The width is rapidly increased, and the river width corresponding to the water level of $7 \mathrm{~m}$ and $10 \mathrm{~m}$ are $6879 \mathrm{~m}$ and 29,288 m, respectively, and the river width added for the unit river depth reaches $7470 \mathrm{~m}$; the section area of the river corresponding to the water level of $7 \mathrm{~m}$ and $10 \mathrm{~m}$ are $12,766 \mathrm{~m}^{2}$ and $48,211 \mathrm{~m}^{2}$, and the channel section area added for the unit water depth reaches $11,815 \mathrm{~m}^{2}$.

During the period of the Mekong River flood reverse flow to Tonle Sap Lake from 1995 to 2008, the water level difference between Prek Kdam Station and Phnom Penh Port Station under different water level and flow conditions of Prek Kdam Station is shown in Table 4, and the relationship between the water level difference and discharge of Prek Kdam Station is shown in Figure 20. It can be seen that: the water level difference in the exit section of the Tonle Sap Lake is larger at low water levels and larger flows. When the water level of Prek Kdam Station is at $3.5-4.5 \mathrm{~m}, 4.5-5.5 \mathrm{~m}, 5.5-6.5 \mathrm{~m}, 6.5-7.5 \mathrm{~m}, 7.5-8.5 \mathrm{~m}$, the 
Table 4. The water level difference (WLD) between Prek Kdam Station and Phnom Penh Port Station required for different water level and flow conditions of Prek Kdam Station.

\begin{tabular}{|c|c|c|c|c|c|c|c|c|c|c|c|}
\hline $\begin{array}{l}\text { Water level of Prek } \\
\text { Kdam Station (m) }\end{array}$ & Discharge & Prek Kd & Station & $\left.\mathrm{n}^{3} / \mathrm{s}\right)$, wa & level dif & ence bc & en Prel & lam an & inom $\mathrm{Pe}$ & Port sta & ons (m) \\
\hline \multirow{2}{*}{$1.5-2.5$} & Discharge & -1000 & & & & & & & & & \\
\hline & WLD & -0.63 & & & & & & & & & \\
\hline \multirow{2}{*}{$2.5-3.5$} & Discharge & -1000 & -2000 & & & & & & & & \\
\hline & WLD & -0.34 & -1.10 & & & & & & & & \\
\hline \multirow{2}{*}{$3.5-4.5$} & Discharge & -1000 & -2000 & -3000 & -4000 & -5000 & & & & & \\
\hline & WLD & -0.07 & -0.56 & -0.97 & -1.35 & -2.29 & & & & & \\
\hline \multirow{2}{*}{$4.5-5.5$} & Discharge & -1000 & -2000 & -3000 & -4000 & -5000 & -6000 & & & & \\
\hline & WLD & 0.00 & -0.30 & -0.40 & -1.04 & -1.43 & -1.57 & & & & \\
\hline \multirow{2}{*}{$5.5-6.5$} & Discharge & -1000 & -2000 & -3000 & -4000 & -5000 & -6000 & -7000 & -8000 & & \\
\hline & WLD & 0.02 & -0.13 & -0.30 & -0.45 & -1.04 & -1.09 & -1.42 & -2.10 & & \\
\hline \multirow{2}{*}{$6.5-7.5$} & Discharge & -1000 & -2000 & -3000 & -4000 & -5000 & -6000 & -7000 & -8000 & -9000 & \\
\hline & WLD & 0.07 & 0.05 & -0.12 & -0.21 & -0.53 & -0.93 & -1.17 & -1.29 & -2.31 & \\
\hline \multirow{2}{*}{$7.5-8.5$} & Discharge & -1000 & -2000 & -3000 & -4000 & -5000 & -6000 & -7000 & -8000 & -9000 & $-10,000$ \\
\hline & WLD & 0.03 & 0.04 & -0.04 & -0.11 & -0.18 & -0.46 & -0.77 & -0.91 & -1.30 & -2.00 \\
\hline
\end{tabular}

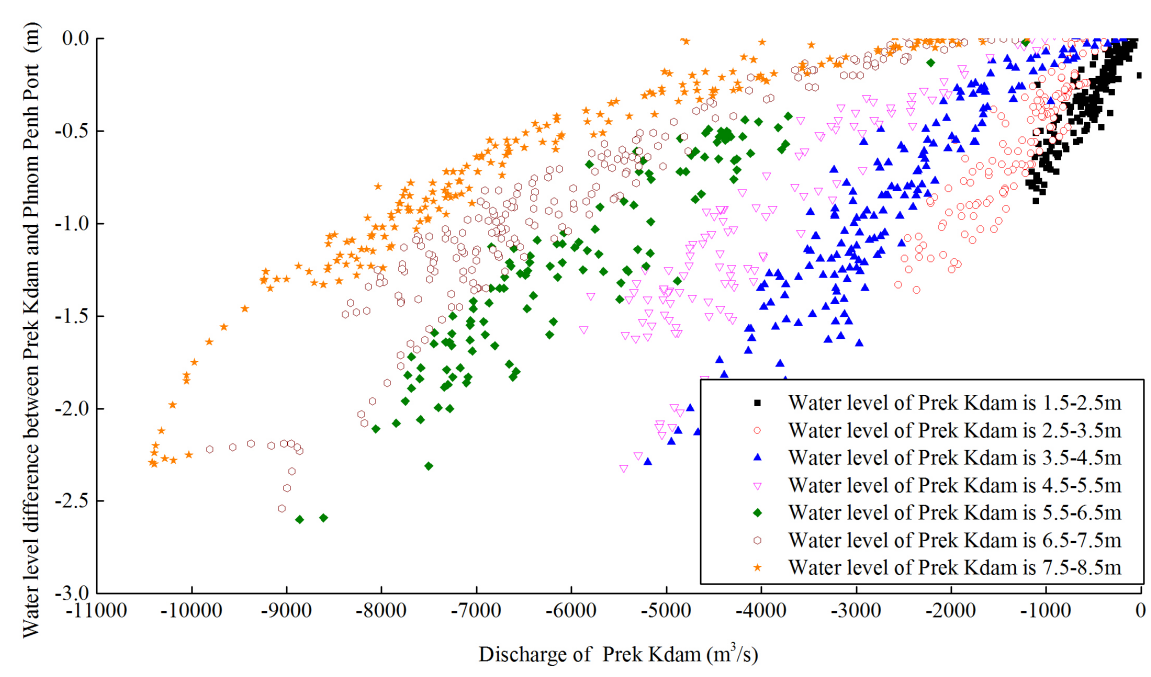

Figure 20. Relationship between the water level difference and discharge of Prek Kdam Station.

water head difference required for the reverse flow of $5000 \mathrm{~m}^{3} / \mathrm{s}$ is $-2.29 \mathrm{~m}, 1.43$ $\mathrm{m},-1.04 \mathrm{~m},-0.53 \mathrm{~m}$ and $-0.18 \mathrm{~m}$, respectively. When the reverse flow is 3000 $\mathrm{m}^{3} / \mathrm{s}, 4000 \mathrm{~m}^{3} / \mathrm{s}, 5000 \mathrm{~m}^{3} / \mathrm{s}, 6000 \mathrm{~m}^{3} / \mathrm{s}, 7000 \mathrm{~m}^{3} / \mathrm{s}, 8000 \mathrm{~m}^{3} / \mathrm{s}, 9000 \mathrm{~m}^{3} / \mathrm{s}$ and $10,000 \mathrm{~m}^{3} / \mathrm{s}$, the head difference required for the water level of Prek Kdam Station at $7.5-8.5 \mathrm{~m}$ is $-0.04 \mathrm{~m},-0.11 \mathrm{~m},-0.18 \mathrm{~m},-0.46 \mathrm{~m},-0.77 \mathrm{~m},-0.91 \mathrm{~m}$, $-1.30 \mathrm{~m}$ and $-2.00 \mathrm{~m}$. According to the measured data, the backflow occurs mostly during the high water level, and the reverse discharge almost does not 
exceed $10,000 \mathrm{~m}^{3} / \mathrm{s}$, so the required water head difference rarely exceeds $-2.0 \mathrm{~m}$. When the backflow is small, the water level difference needed is very low.

During the period of water replenishment from Tonle Sap Lake to Mekong River, the relationship between the discharge of Prek Kdam Station and the water level difference between Prek Kdam and Phnom Penh Port and the water level of Prek Kdam station is similar, and it's not described in detail this time.

Above all, the main hydrological conditions of reverse flow from Mekong River to Tonle Sap Lake and water replenishment from Tonle Sap Lake to Mekong River are the river-lake water level difference and the water level of Tonle Sap River. Of which, river-lake water level difference can be reflected by the water level difference between Prek Kdam and Phnom Penh Port, and it reflects the flow resistance at the outlet section of Tonle Sap Lake. The water level of Tonle Sap River can be reflected by the water level of Prek Kdam station, and it reflects the cross-sectional area of Tonle Sap River. The backflow and replenishing flow increase with the increase of river-lake water level difference and expand with the rise of the water level of Tonle Sap River.

\section{Conclusions}

According to the topographic data and long series of hydrological data of the Mekong Delta and the Tonle Sap Lake, the morphological characteristics, water level variation characteristics and the response relationship between them were analyzed, and the river-lake water exchange pattern and its response relationship to river-lake morphological characteristics were studied. The results show:

1) The terrain of the Mekong Delta and the Tonle Sap Lake is flat. The Mekong River and Tonle Sap Lake interact with each other strongly, resulting complicated hydrological situation. The highest and lowest water levels in the Tonle Sap Lake occur in October and May respectively. The highest and lowest water levels in the Mekong Delta happened in September and April respectively. Affected by the morphological characteristics of Mekong River and Tonle Sap Lake, the water exchange pattern between them has the following features: the Mekong River reversely flows into the Tonle Sap Lake from June to September every year, and the storage water of Tonle Sap Lake flows out to the Mekong River in the dry season from October to May. The water exchange intensity of them is enormous, which makes the Tonle Sap Lake have a significant effect of the peak cutting and water replenishing on the Mekong River. The reverse flow lasts an average of 127 days per year, reducing flood peak discharge by 6857 $\mathrm{m}^{3} / \mathrm{s}$, whose peak reduction rate is up to $15.6 \%$, stores flood voume totaling 39.7 billion $\mathrm{m}^{3}$, which accounted for $14.4 \%$ of flood voume of Mekong River. The forward flow lasts an average of 238 days per year, and the amount of water supply to Mekong River is 69.4 billion $\mathrm{m}^{3}$, accounting for $29.7 \%$ of the inflow in the lower reaches of the Mekong River, which is 2.6 times as large as the area ratio, and 1.77 times as large as the reverse volume.

2) Both of Cambodia Mekong Delta and Tonle Sap Lake Area are low-lying land. Currently, the flood control capacity of most reaches is 5 - 10-year return 
period with converging flow into main channel in the dry season and flood overbanking in the rainy season; the flood relationships between the left and right banks and between Mekong River and Tonle Sap Lake are complicated. Besides, overland flood of Mekong Delta often occurs at Kampong Cham-Phnom Penh section, where the average overland flood volume in June-November is about 31.2 billion $\mathrm{m}^{3}$, accounting for $8.7 \%$ of the total volume at the upstream Kampong Cham Station. The overbank flood mainly concentrates from August to September, and the flood volume accounts for $65 \%-72 \%$ of the total volume. Tonle Sap Lake is the floodplain of the Mekong Delta, influenced by the reverse flow of the Mekong River and the inflow from the Tonle Sap Lake basin, the area and volume of the Tonle Sap Lake during the flood and dry seasons are quite different. The water level of Tonle Sap Lake increases gradually from May to Oct., and reaches the maximum value in Oct., when the average water level is $8.70 \mathrm{~m}$, and the corresponding area is $12,767.9 \mathrm{~km}^{2}$ and volume is 52.88 billion $\mathrm{m}^{3}$. The lowest water level of Tonle Sap Lake sees in May, when the average water level is $1.51 \mathrm{~m}$, and the corresponding area is $2486.5 \mathrm{~km}^{2}$ and volume is 1.68 billion $\mathrm{m}^{3}$. The multi-year average annual water level variation range is $7.92 \mathrm{~m}$, the relevant lake area variation range is $11,097 \mathrm{~km}^{2}$, and the water storage variation range is 59.5 billion $\mathrm{m}^{3}$.

3) Affected by the function of dispelling flood peak and compensating water of the floodplain in the Mekong Delta and the Tonle Sap Lake, the water level variation range of Mekong River declines from top to bottom. The annual average water level variation range in Kampong Cham, Chaktomuk, Neak Luong and Koh Khel are 2.59 m, 2.27 m, 1.56 m, 1.40 m. Additionally, the water surface ratio tends to be gentle and far less than the river channel ratio, the average water surface ratio of the Kampong Cham-Chaktomuk section in Mekong River, Chaktomuk-Koh Khel section in Bassac River and Kampong Luong-Prek Kdam section in Tonle Sap Lake Area are $0.0198 \%$, 0.0198\%o and 0.00598\%o. The water level fluctuation tends to be gentle, the average daily water rising rate of Mekong River decreases from $0.16 \mathrm{~m} / \mathrm{d}$ in the Kampong Cham section to $0.09 \mathrm{~m} / \mathrm{d}$ in the Phnom Penh section and $0.07 \mathrm{~m} / \mathrm{d}$ in the Koh Khel section, and the average daily water rising rate of Tonle Sap Lake decreases from $0.08 \mathrm{~m} / \mathrm{d}$ in the Prek Kdam section to $0.06 \mathrm{~m} / \mathrm{d}$ in the Kampong Luong section. Also, the annual average daily water withdrawalling rate of Mekong River is reduced from $0.09 \mathrm{~m} / \mathrm{d}$ in the Kampong Cham section to $0.06 \mathrm{~m} / \mathrm{d}$ in the Phnom Penh section and 0.05 $\mathrm{m} / \mathrm{d}$ in the Koh Khel section, and annual average daily water withdrawalling rate of Tonle Sap Lake decreases from $0.053 \mathrm{~m} / \mathrm{d}$ in the Prek Kdam section to 0.0459 $\mathrm{m} / \mathrm{d}$ in the Kampong Luong section. Besides, the water level rising rate and withdrawalling rate are positively correlated with the floodplain storage area.

4) The timing and intensity of water exchange between the Mekong River and the Tonle Sap Lake are closely related to the water level difference between them and the water level of Tonle Sap River. When the water level of the Mekong River is higher than that of Tonle Sap Lake, and the flood from the Mekong River will reversely flow to the Tonle Sap Lake. When the water level of the Mekong 
River is lower than that of Tonle Sap Lake, the water of Tonle Sap Lake will replenish to Mekong River. The amount of water for the reverse and replenishing flows increase with the rise of the water level difference. Under the same water level difference conditions, the volume of backflow and replenishing flow increase with the rise of the water level of the Tonle Sap River. The river-lake water level difference shows the water flow resistance at the exit part of Tonle Sap Lake. The water level of the Tonle Sap River reflects the changing characteristics of the cross-sectional area of the Tonle River during the flood season and dry season.

\section{Acknowledgements}

The authors gratefully acknowledge the support of the "National Key Research and Development Program of China" (Grant No. 2017YFC0405301 and Grant No. 2018YFC1508005); China-Asean Maritime Cooperation Fund "Langcang-Mekong Water Resources Cooperation Project".

\section{Conflicts of Interest}

The authors declare no conflicts of interest regarding the publication of this paper.

\section{References}

[1] Mekong River Commission (2005) Overview of the Hydrology of the Mekong Basin. Mekong River Commission, Vientiane.

[2] Changjiang Water Resources Commission of the Ministry of Water Resources (2018) Outline of Master Plan on Water Resources of Cambodian. Changjiang Water Resources Commission, Wuhan. (In Chinese)

[3] Mekong River Commission (2011) Flood Situation Report 2011. Mekong River Commission, Phnom Penh.

[4] Sogreah. (1966) Modèle Mathématique de Delta du Mekong: Rapport d'ensemble sur les différentes déterminations de la Capacité de Grand Lac. Société Grenobloise d'études et d'applications hydrauliques, Grenoble.

[5] Li, C.W., You, Z.Q. and Yao, W. (2018) Study on the Flood Storage Function of Tonle Sap Lake. Proceedings of 2018 Annual Conference of Chinese Hydraulic Engineering Society. The Third Volume, Nanchang, 20-22 October 2018, 351-355. (In Chinese)

[6] Sopharith, T. (1997) Hydrological Studies of the Tonle Sap/Great Lake Area. Ministry of Agriculture, Forestry and Fishery, Phnom Penh.

[7] Teng, P.S. (1998) Monitoring of Water Surface and Estimation of Water Volume of Tonle Sap Lake Using Satellite Imagery. Asian Institute of Technology, Bangkok.

[8] Jantunen, T. (2001) Volumetric Study of the Great Lake Tonle Sap, Cambodia. Dundee, UK.

[9] Karri, E., Hellsten, S. Jantunen, T., Jozsa, T., Kiirikki, M., Lauri, H., Koponen, J., Sarkkula, J., Varis, O. and Virtanen, M. (2002) Water Utilization Program-Modelling of the Flow Regime and Water Quality of the Tonle Sap (WUP-FIN). Mekong River Commission, Phnom Penh. 
[10] Mak, S., Pheng, S., Khuon, K., Sin, C., Tes S., Chea T., Vang, R. and Sou, V. (2011) Profile of The Tonle Sap Sub-area (SA-9C). Cambodia National Mekong Committee, Phnom Penh.

[11] Kummu, M., Savuth, Y., Sarkkula, J., Koponen, J., Adamson, P. and Tes, S. (2006) Hydrological, Environmental and Socio-Economic Modelling Tools for the Lower Mekong Basin Impact Assessment: Tonle Sap Lake water balance calculations, Technical Paper No.5. WUP-FIN Phase II. Mekong River Commission, Phnom Penh.

[12] Li, C.W., You, Z.Q., Xu, Z.M. and Huang, L.Y. (2019) Time and Magnitude Variety Characteristics of Water Exchange between Mekong River and Tonle Sap Lake. Journal of Yangtze River Scientific Research Institute, 1-7 (In Chinese). http://kns.cnki.net/kcms/detail/42.1171.TV.20190723.1538.022.html

[13] Li, C.W., You, Z.Q., Yao, W., Xu, Z.M. and Yuan, D. (2018) Study on Hydrologic Condition of Water Exchange Between Mekong River and Tonle Sap Lake. Proceedings of 2018 Annual Conference of Chinese Hydraulic Engineering Society One Belt One Road•Go Out, Nanchang, 20-22 October 2018, 166-174. (In Chinese)

[14] Li, C.W., Xu, Z.M., You, Z.Q., et al. (2019) Flood and Flood Disaster Characteristics of Mekong River and Related Counter-Measures for Flood Control. Yangtze River, 50, 35-45. (In Chinese)

http://www.wanfangdata.com.cn/details/detail.do?_type=perio\&id=rmcj201907008

[15] Republic of Korea, Korea International Cooperation Agency, Korea Water Resources Corporation (2008) Master Plan of Water Resources Development in Cambodia. Ministry of Water Resources and Meteorology, The Kingdom of Cambodia, Phnom Penh.

[16] Mak, S., Pheng, S., Khuon, K., Sin, C., Tes, S., Chea, T., Vang, R. and Sou, V. (2011) Profile of the Cambodia Mekong Delta Sub-Area (SA-10C). Cambodia National Mekong Committee, Phnom Penh.

[17] Cochrane, T.A., Arias, M.E. and Piman, T. (2014) Historical Impact of Water Infrastructure on Water Levels of the Mekong River and the Tonle Sap System. Hydrology and Earth System Sciences, 18, 4529-4541.

https://www.researchgate.net/publication/261879218 https://doi.org/10.5194/hess-18-4529-2014

[18] Matti, K. and Juha, S. (2008) Impact of the Mekong River Flow Alteration on the Tonle Sap Flood Pulse. Ambio, 37, 185-192.

https://www.ncbi.nlm.nih.gov/pubmed/18595273 https://doi.org/10.1579/0044-7447(2008)37[185:IOTMRF]2.0.CO;2

[19] Dirk, L. and Jorma, K. (2008) Flood Pulse Alterations and Productivity of the Tonle Sap Ecosystem: A Model for Impact Assessment. Ambio, 37, 178-184.

http://www.wanfangdata.com.cn/details/detail.do?_type=perio\&id=rmcj201907008 https://doi.org/10.1579/0044-7447(2008)37[178:FPAAPO]2.0.CO;2

[20] Royal Haskoning, Deltares, UNESCO-IHE. (2010) The Flood Management and Mitigation Programme, 'Component 2: Structural Measures and Flood Proofing in the Lower Mekong Basin’. Mekong River Commission, Vientiane.

[21] Sopharith, T., Saing, I.S., Des, C. and Nigel, H. (2014) Cambodian Water Resources Profile. Ministry of Water Resources and Meteorology, Phnom Penh.

[22] NFFC Consultant Team of EPTISA and KCC (2016) Conceptual Design Report Forecast Production and Dissemination. National Flood Forecasting Centre, Phnom Penh. 